\title{
Decarbonization and its discontents: a critical energy justice perspective on four low-carbon transitions
}

\author{
Benjamin K. Sovacool ${ }^{1,2}$ (D) $\cdot$ Mari Martiskainen ${ }^{1} \cdot$ Andrew Hook $^{1} \cdot$ Lucy Baker $^{1}$
}

Received: 16 December 2018 / Accepted: 8 August 2019 / Published online: 21 August 2019

(C) The Author(s) 2019

\begin{abstract}
Low-carbon transitions are often assumed as positive phenomena, because they supposedly reduce carbon emissions, yet without vigilance, there is evidence that they can in fact create new injustices and vulnerabilities, while also failing to address pre-existing structural drivers of injustice in energy markets and the wider socio-economy. With this in mind, we examine four European low-carbon transitions from an unusual normative perspective: that of energy justice. Because a multitude of studies looks at the co-benefits of renewable energy, low-carbon mobility, or climate change mitigation, we instead ask in this paper what are the types of injustices associated with low-carbon transitions? Relatedly, in what ways do low-carbon transitions worsen social risks or vulnerabilities? Lastly, what policies might be deployed to make these transitions more just? We answer these questions by first elaborating an "energy justice" framework consisting of four distinct dimensions - distributive justice (costs and benefits), procedural justice (due process), cosmopolitan justice (global externalities), and recognition justice (vulnerable groups). We then examine four European low-carbon transitions-nuclear power in France, smart meters in Great Britain, electric vehicles in Norway, and solar energy in Germany-through this critical justice lens. In doing so, we draw from original data collected from 64 semi-structured interviews with expert participants as well as five public focus groups and the monitoring of twelve large internet forums. We document 120 distinct energy injustices across these four transitions, including 19 commonly recurring injustices. We aim to show how when low-carbon transitions unfold, deeper injustices related to equity, distribution, and fairness invariably arise.
\end{abstract}

Benjamin K. Sovacool

B.Sovacool@sussex.ac.uk

1 Science Policy Research Unit (SPRU), School of Business, Management, and Economics, University of Sussex, Jubilee Building, Room 367, Falmer, Brighton, East Sussex BN1 9SL, UK

2 Center for Energy Technologies, Department of Business Development and Technology, Aarhus University, Aarhus, Denmark 


\section{Introduction}

It is becoming a commonly accepted truism that we must minimize vulnerability to the interrelated socio-economic and environmental risks associated with continued fossil fuel consumption (Grubb 2014). Such a challenge requires concentrated and unified efforts towards a low-carbon transition and "deep decarbonization" (Geels et al. 2017). But while the goal of reducing the carbon (and resource) intensity of economic activity has often been treated as a technical task that can be modeled by "science" and administered by "policy," there has been an increasing recognition that decarbonization is a challenge that is inherently entangled in the social realm -in politics, economics, culture, geography, and knowledge (Smith and Stirling 2010; Sovacool 2014; Geels et al. 2016).

In this regard, a flurry of work in social scientific fields as diverse as energy policy, climate policy, environmental science, geography, and innovation studies has begun to examine the social dimensions of pathways (in the broadest sense) towards deep reductions in global emissions (Creutzig et al. 2018; Green and Denniss 2018; Geels et al. 2018; IPCC 2019). Such work has focused on issues as varied as the political-economic dynamics determining incumbent industry power (Geels 2014); the social psychology of public climate change engagement (Shove 2010); the differentiated diffusion of low-carbon technology between and across societies (Ockwell et al. 2010); the carbon footprint associated with low-carbon technologies (Mulvaney 2013, 2014); and the regulatory policies that can stimulate low-carbon house-building (Horne and Dalton 2014).

One such sub-set of approaches to energy analysis - energy justice - has increasingly emphasized the potential justice dimensions of low-carbon energy systems and transitions (McCauley et al. 2019). Although the roots of an energy justice approach are deep, and date back until at least the 1980s (Perez-Guerrero 1982; Weinberg 1985), more recent works have applied energy justice principles or concepts to the topic of low-carbon transitions. Scholars in this tradition have - somewhat counter-intuitively - argued that, while low-carbon transitions may well represent normative "goods" in the sense that they contribute to reductions in carbon dioxide, they may also generate new - or worsen pre-existing - inequalities in society (Newell and Mulvaney 2013). After all, all major socio-technical transitions require open and democratic participation by a wide range of actors (including firms and consumers, as well as civil society groups, media advocates, community groups, city authorities, political parties, advisory bodies, and government ministries) to minimize unwanted impacts (Bickerstaff et al. 2013). As such, successful low-carbon transitions must be based around shared beliefs, values, interests, resources, skills, and relations that are under-pinned by understandings of the need for pathways towards sustainability (Demski et al. 2015). A failure to facilitate the participation of all citizens may not only make for less responsive and representative policy choices; it may also create friction and resentment in society, widening exclusion and inequality (Barry and Ellis 2011).

With this in mind, we examine four European low-carbon transitions from an unusual perspective, where we evaluate the ethical and moral dimensions of transitions: that of energy justice. Because numerous studies have already focused on the justice benefits or co-benefits to renewable energy, low-carbon mobility, or climate change mitigation (see for example Alberini et al. 2018; Burke et al. 2018; Noel et al. 2018; Ürge-Vorsatz et al. 2014), we instead ask in this paper what are the types of injustices associated with low-carbon transitions? Relatedly, in what ways do low-carbon transitions worsen social risks or vulnerabilities? Lastly, what policies might be deployed to make these transitions more just?

By asking these questions, we aim to unveil, firstly, those who may be vulnerable and negatively impacted, and, secondly, the underlying political and structural issues that recreate vulnerabilities in low-carbon transitions. We answer these questions by first elaborating an 
energy justice framework consisting of four distinct dimensions: distributive justice (costs and benefits), procedural justice (due process), cosmopolitan justice (global externalities), and recognition justice (vulnerable groups) (McCauley et al. 2019; Sovacool et al. 2019). We then examine four European transitions being promoted as templates for low-carbon policy around the world - nuclear power in France, ${ }^{1}$ smart meters in Great Britain, electric vehicles in Norway, and solar energy in Germany-through this critical justice lens. In doing so, we draw from original data collected from 64 semi-structured interviews with expert participants as well as five public focus groups and the monitoring of twelve internet forums, and identify 120 unique energy injustices with these transitions.

The prime contribution of the study lies in offering a normative justice perspective that can provide a means to unsettle or challenge the dominant positioning in the technical and economic literature of low-carbon transitions as perpetually positive, neutral, or amoral. Numerous studies have already estimated and analyzed the litany of co-benefits offered by low-carbon transitions, but very few (if any at all) have carefully calculated the injustices, or the dis-benefits. Indeed, despite the fact that many of our own expert interview participants stated that they believed low-carbon transitions had no discernable losers, others drew attention to distinct equity, distribution, and fairness dimensions (even when the net effect of a transition may still be a social gain). One cannot identify and manage what they do not (currently) measure, and here, we maintain there is empirical novelty in documenting these injustices. We also examine a range of practical policy implications or actions that can minimize the vulnerabilities and injustices we identify.

\section{Case selection and research methods}

First, we decided that countries served as our best unit of analysis, rather than individual projects, companies, or other types of actors such as transnational firms or governance networks. This is because, as Brown et al. (2014: 5) states, "the nation state remains where most energy planning and policymaking takes place, and it is also how most major energy statistics are collected, based on national boundaries." In addition, notwithstanding the recognition of the "new modes of governance" that lie above and below countries (Florini and Sovacool 2009), a majority of important political decisions are still made at the state level, and the state-based international system has demonstrated a high degree of coherence and durability (Falkner 2013; Andrews and Nwapi 2018). Countries also hold significant positive potential in their ability to address major challenges such as climate change and energy transitions (Johnstone and Newell 2018). As such, Eckersley (2004: iv) calls states the "gatekeepers of the global order," and adds that they remain the "preeminent political institution for addressing environmental problems."

We then selected four national case studies to represent a European or world leader in two sets of low-carbon technologies, two supply oriented (nuclear power, solar energy) and two demand/end-use oriented (electric vehicles, smart meters). France is well known for being a major nuclear power producer and exporter. With 58 nuclear reactors, France produces $75 \%$ of its electricity from nuclear fission (World Nuclear Association 2018), and it has also exported nuclear technology to other countries. Plants with French nuclear technology operate in China,

\footnotetext{
${ }^{1}$ This is a somewhat contentious choice as France's nuclear transition was launched in the pre-climate change era and there is much debate around whether it should still be considered a "low carbon" choice. However, it remains a relevant source of analysis because for many-including, for example, the influential International Energy Agency (IEA), it remains "on the table" as an option, particularly for what they term "developing economies."
} 
South Africa, and South Korea, are under construction in Finland, and planned for in Turkey and the UK (World Nuclear Association 2018). Germany leads the world in its total installed capacity of solar panels per capita (German Federal Ministry for Economic Affairs and Energy 2017). With a history in developing solar R\&D and creating an early domestic market through specific policy support measures, Germany has had a profound impact on global solar development. Norway is the world leader for the per capita deployment of battery electric vehicles, or EVs (International Energy Agency 2018), following long-standing policy support for those purchasing and using EVs. Great Britain has distributed approximately 12.3 million smart meters to residences and small businesses as of early 2018 and plans to offer them to every household by 2020 (BEIS, 2018). Great Britain's smart meter roll involves the potential installation of 53 million meters, making it the largest behavioral change program in Britain, maybe even the world (House of Commons Science and Technology Committee, 2016). Our cases are also at different stages regarding when transitions begun, with France providing the most historical case with their nuclear program accelerating under the Messmer Plan in the 1970s, Norway introducing EV policies in the 1990s, Germany implementing its feed-in tariff for solar energy via the Energiewende in the 2000s, and Britain entering the main phase for smart meters in the 2010s.

Following national case study selection, we proceeded with a qualitative research design that mixed methods across three approaches. We conducted 64 expert interviews in the summer and fall of 2018 with a mix of respondents from academia, civil society, industry, and government, summarized in Table 1. In each interview, we asked (among other questions) what do you see as some of the most significant injustices or disadvantages to the energy transition being examined? The research interviews were digitally recorded, generally lasted between 30 and $90 \mathrm{~min}$, and participants were guaranteed anonymity to protect their identity and encourage candor.

To supplement our expert interviews with data from the ordinary public, we conducted five focus groups in non-capital areas of each country, namely Lewes (Great Britain), Colmar (France), Freiburg (Germany, two focus groups), and Stavanger (Norway). We followed the same protocol as the interviews, asking the same semi-structured questions, with more details also provided in Table 1 .

To triangulate our interviews and focus groups, we posted research questions on large and publicly accessible online internet forums, three per country, to solicit public input beyond the focus groups. This resulted in 58 additional responses posted on places such as the Elbilforum.no (Norway), Solarstrom-forum.de (Germany), forum.ovoenergy.com (Great Britain), and forumphotovoltaique.fr (France). Table 1 offers more detail about the internet forums as well.

After collection of the interview, focus group, and internet forum data, these were transcribed, and each respondent was given a unique identifying number. To ensure reliability within the research team, each interview was then coded by at least two researchers, to ensure nothing was missed. Every transcript was coded, and then placed into a single file using a software program called Nvivo, which allows transcripts to be stored and searched by keywords and content. To ensure reliability, the Nvivo file was shared and utilized by all authors.

Despite an attempt at triangulation within these methods, our approach does have some notable weaknesses. Although the focus groups and internet forums were open to all members of the public, the number of responses collected was less than that of the expert interviews. Moreover, due to presenting a wealth of new empirical material spread across four case studies, we did not have sufficient space in this paper to conduct a rigorous literature review to confirm our findings. We lastly did not make an attempt to weight, correct, normalize, or problematize data across our methods, to avoid censoring our results and discussion. This also 


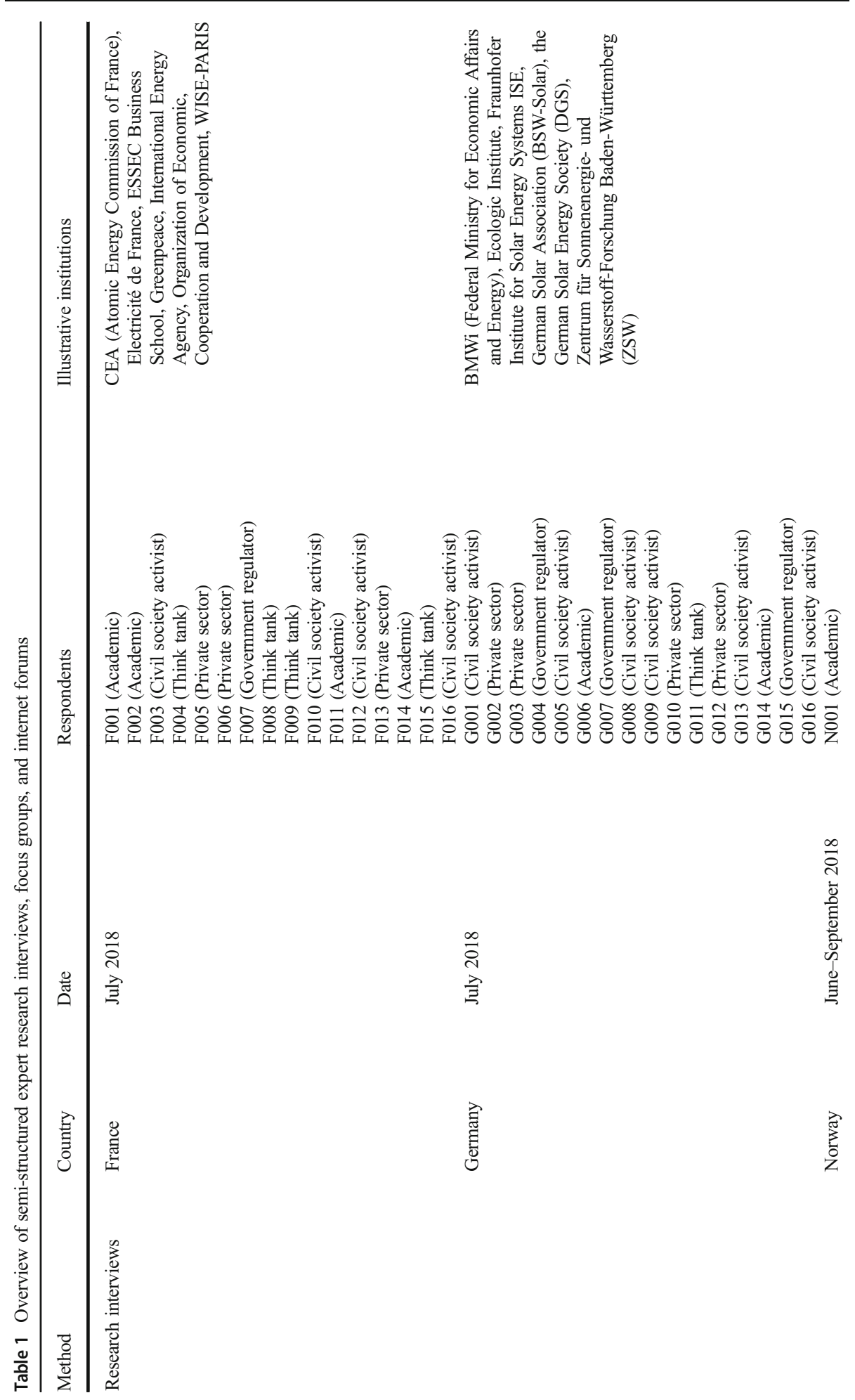




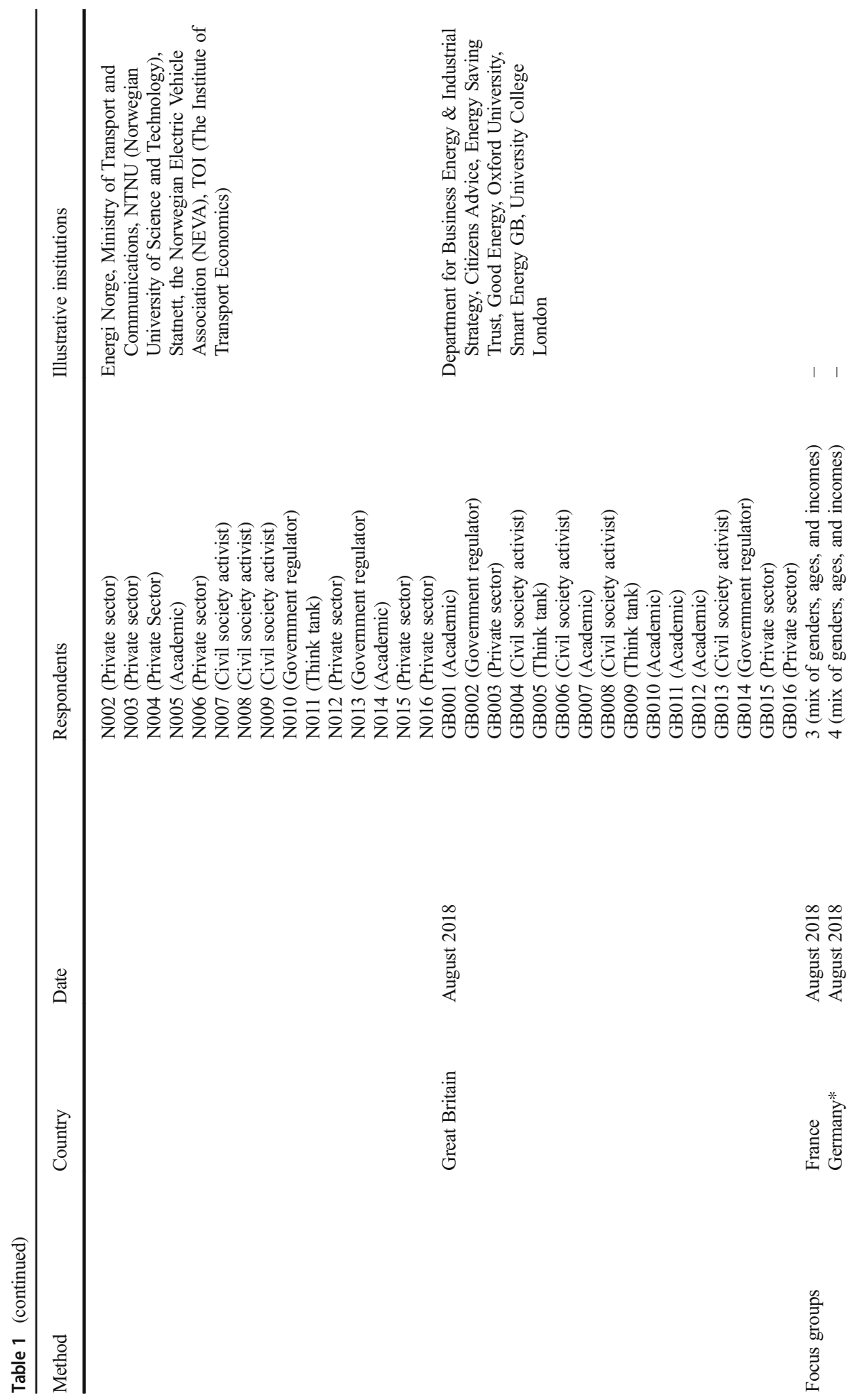




$$
\sqrt{1}
$$


ensured we met the justice principle of "recognition," namely that the concerns of all respondents were respected and treated as valid (Jenkins et al. 2016).

\section{Conceptual framework: energy justice}

One notable strand of the socio-technical literature on energy systems and transitions has been the emerging field of energy justice, a normative framework for appraising the ways in which energy systems and transitions may inadvertently create or entrench unfairness or inequities within society (Jenkins et al. 2016). While typically focusing on injustices related to the preexisting (and fossil fuel-intensive) energy system (e.g., Schlosberg and Carruthers, 2010; Healy et al. 2019), an emerging body of literature in this sub-field has turned its attention to explicitly examining the justice dimensions of low-carbon transitions themselves. In this vein - and contrary to conventional thinking on low-carbon energy which often uncritically assumes it to be inherently more just and democratic than the incumbent system (e.g., as Newell and Mulvaney 2013; Burke et al. 2018 have discussed) - the emerging work has explored issues such as the mineral extraction underwriting "smart" technologies (Mulvaney 2013, 2014), the uneven economic costs of "green" transitions (Evensen et al. 2018), and the impacts of "low-carbon" energy infrastructure on communities (Yenneti and Day, 2015).

While recognizing that a focus on minimizing injustice is often rationalized in more pragmatic or instrumental terms (i.e., from the perspective that, if large numbers of people are excluded from a transition — or are actively disadvantaged by it - it may hinder the transition itself or generate unintended conflict and resentment among those who are excluded), energy justice authors argue that potential injustices within energy transitions should be considered as valid normative concerns in their own right (Jones et al. 2015; Goedkoop and Devine-Wright 2016; Bickerstaff 2017).

To analyze and filter our data across our four case studies, we utilize a specific holistic framework of energy justice recently presented by McCauley et al. (2019) and Sovacool et al. (2019). This approach consists of four interconnected aspects of modern justice theory: distributive justice, procedural justice, cosmopolitan justice, and justice as recognition.

\subsection{Distributive justice}

As McCauley et al. (2019) and Sovacool et al. (2019) explore, distributive justice deals with how social goods and ills are allocated across society. Generally, distributive justice deals with spatial and temporal issues that can be divided into three aspects of distribution: identifying the goods and ills that are being distributed (e.g., food, clothing, power, wealth, or respect); identifying the entities between whom or what they are to be distributed (e.g., members of certain communities or stakeholders, certain generations, all of humankind); and identifying the most appropriate mode of distribution as well as what this is based on (e.g., status, need, merit, rights). With regard to lowcarbon transitions, concepts from distributive justice can help in developing energy systems in which costs are shared and participants benefit as equally as possible.

\subsection{Procedural justice}

Issues of public participation, due process, and representative justice are central to procedural justice (McCauley et al. 2019; Sovacool et al. 2019). Procedural justice generally focuses on 
identifying those who plan and make rules, laws and decisions, and those who can have a say in such processes. It also focuses on seeking to unveil the fairness of the processes through which decisions are made. Process or deliberative democracy are relevant to the theories of procedural justice, as well as to dimensions such as accessibility, open participation, transparency, fair representation, impartiality, and objectivity. Fair procedures matter in low-carbon transitions, as they can enable systems that are designed in ways that promote more equitable outcomes.

\subsection{Cosmopolitan justice}

Cosmopolitan justice takes a universal approach and centers on the notion that all human beings in all nations are bound and protected by moral principles (McCauley et al. 2019; Sovacool et al. 2019). From this perspective, all human beings have equal moral worth regardless of ethnicity, gender, or social status. They also have a collective morality and responsibility for others that goes beyond borders. Cosmopolitan justice focuses on ensuring the wellbeing of persons, rather than communities or nations, treating every human equally. As members of a global community of human beings, cosmopolitan justice "holds that the way to individual and communal mutual benefit is to treat others as they themselves would wish to be treated" (Sovacool et al. 2019: 6).

\subsection{Recognition justice}

Finally, recognition justice focuses on identifying vulnerable people whose vulnerability may be worsened as a result of a process such as a low-carbon transition, for example. Recognition justice centers on unveiling those who may face intolerance and discrimination and supports the idea that they should be guaranteed a fair representation of their views without distortion or fears of reprisal (McCauley et al. 2019; Sovacool et al. 2019). Recognition justice thus places emphasis on understanding differences alongside protecting equal rights for all. For example, in low-carbon transitions, there may be vulnerable groups of people, such as the chronically poor, the ill, or the unemployed, who need special representation and treatment in order to be protected from further harm.

\subsection{Intersections and interconnections}

When reflecting on these four streams of justice theory, distributive and procedural justice form a foundation and relate to how access to the technology, costs, and/or benefits are distributed, or how impartial and fair (or unfair) decision-making processes and policy fora are. Indeed, much justice literature focuses only on these two streams. However, cosmopolitan justice adds a spatial component to this analysis, revealing either distributive or procedural injustices that can arise well beyond the community in question - in our case, outside of the geographic context of our four European countries. Then, recognition justice adds a final layer of vulnerability on top of distribution, procedures, and scale. Whenever a distributive, procedural, or cosmopolitan injustice impacted a particularly vulnerable group, we moved it out of that category and classified it as a recognition concern. This meant that we classified recognition justice concerns last, but also that we kept our classifications mutually exclusive, so a particular injustice could fall into only one of our sections. This is also how McCauley et al. (2019) and Sovacool et al. (2019) applied the framework. Nonetheless, as we will see, 
there are multiple overlaps between the sections, a complexity we believe is as accurately descriptive as it is messy.

\section{Unveiling the injustices of four low-carbon transitions}

Our analysis of the data from expert interviews, focus groups, and internet forums identified 120 injustices in the four energy justice dimensions in all of the four case studies. An overview of the injustices that were identified by our analysis is given in Table 2, and presented in more detail in sections 4.1-4.4.

Before we present our results, though, we note that some of our expert interviewees specifically pointed out that, in their view, there were no injustices related to the four cases. In Great Britain, GB014 stated that, with respect to smart meters, "I genuinely don't see any social, economic, or environmental disadvantages." Two interviewees in France stated that there were no vulnerable groups in the transition to nuclear power, and similarly in Germany, two interviewees saw the solar energy transition as having no losers. In the case of EVs, seven interviewees could not see any injustices, with N003 saying it was "difficult to see how [EVs] may have such an impact."

While these statements do support the broader perceived utility or net social desirability of a low-carbon transition (compared with the old system), they also however emphasize the apparent invisibility of many of the injustices that were identified by other participants.

\subsection{Distributive justice}

Our material led to the identification of 57 distinct distributive injustices across the four cases examined (Table 3).

For French nuclear power, respondents placed particular emphasis on two distributive injustices, the long-term costs for tax payers and the risk of accidents. F011 elaborated on how nuclear "has a very high and long term cost" and that, even though it had brought low electricity prices, taxes were high and the whole system around nuclear power was costing the French public: "The state has given massive amounts of cash to the sector. Prices are a 'false friend' in many cases. ... There is a lack of concern about the real costs and debate of nuclear energy. Not just the taxes, but the money that has been spent to sustain the whole complex of university and bureaucracy." F004 iterated how nuclear power was asymmetrical in its distribution of costs and benefits, suggesting that "French nuclear development is obviously very centralized, it was about creating jobs and value on a national level. However, most of French electric generation is concentrated in 18 power plants, plus a few facilities like Le Hague. So there are only a few territories that have benefitted from it." In the internet forums, respondents expressed safety concerns, with one person claiming, perhaps in the extreme, that nuclear was "unmanageable and dangerous in the long run" and that "nobody wants to live near a nuclear plant, people think it is ok for my neighbor to, but not me!" As well as being geographically dispersed, the costs of nuclear, both financial and risk-related, were associated with inter-generational justice dimensions, with F004 emphasizing that "the nuclear program implies that long term waste has to be dealt with, disposed of somewhere... So you could discuss the fairness of that kind of project from the perspective of the local territory that will be the host. And you could discuss the fairness towards future generations that will have to deal with that burden." 
Table 2 Overview of energy justice dimensions, definitions, and examples

\begin{tabular}{|c|c|c|}
\hline Dimension & Definition & Illustrative example(s) of injustice \\
\hline $\begin{array}{l}\text { Distributive } \\
\text { justice }\end{array}$ & $\begin{array}{l}\text { Equitable distribution of social and } \\
\text { economic benefits and costs, fair and } \\
\text { open access }\end{array}$ & $\begin{array}{l}\text { France: Uneven concentration of jobs, negative } \\
\text { impacts on property prices near nuclear } \\
\text { infrastructure } \\
\text { Germany: Unemployment in the coal and nuclear } \\
\text { sectors, uneven access to the feed-in tariff (FIT) } \\
\text { Norway: EV ownership limited to those with higher } \\
\text { income, increased traffic congestion for busses, } \\
\text { erosion of revenues for ferry operators } \\
\text { Great Britain: Higher bills across the entire gas and } \\
\text { electricity system, even for non-adopters }\end{array}$ \\
\hline $\begin{array}{l}\text { Procedural } \\
\text { justice }\end{array}$ & $\begin{array}{l}\text { Adherence to due process, fair and } \\
\text { adequate public participation, inclusion } \\
\text { and consent }\end{array}$ & $\begin{array}{l}\text { France: Centralized, authoritarian and secretive } \\
\text { decision-making without broad public consulta- } \\
\text { tion or participation } \\
\text { Germany: The capture of policy by industrial } \\
\text { interests, intentional slowing down of the } \\
\text { transition by incumbents, barriers to entry } \\
\text { Norway: Procedural exclusion of e-bikes, planning } \\
\text { bias towards motorized cars } \\
\text { Great Britain: Lack of public participation, as well } \\
\text { as unjust tactics being used by suppliers to } \\
\text { pressure or mislead people into adopting }\end{array}$ \\
\hline $\begin{array}{l}\text { Cosmopolitan } \\
\text { justice }\end{array}$ & $\begin{array}{l}\text { Protection of global human rights, } \\
\text { accounting and mitigation of global } \\
\text { externalities }\end{array}$ & $\begin{array}{l}\text { France: Uranium mining and exports of nuclear } \\
\text { equipment to countries with poor social, political } \\
\text { and environmental safeguards } \\
\text { Germany: Raw materials, overseas manufacturing, } \\
\text { and waste } \\
\text { Norway: Raw materials, waste flows and overseas } \\
\text { manufacturing } \\
\text { Great Britain: Waste streams and carbon emissions }\end{array}$ \\
\hline $\begin{array}{l}\text { Justice as } \\
\text { recognition }\end{array}$ & $\begin{array}{l}\text { Appreciation for the vulnerable, } \\
\text { marginalized, poor, or otherwise } \\
\text { underrepresented groups }\end{array}$ & $\begin{array}{l}\text { France: Creation of poor housing segment } \\
\text { dependent on inefficient and high priced } \\
\text { electrical heating } \\
\text { Germany: Burdens on families, the elderly, and the } \\
\text { poor } \\
\text { Norway: Enhanced vulnerability of those with } \\
\text { disabilities, single mothers, the elderly, and the } \\
\text { rural poor } \\
\text { Great Britain: Negative impacts on working } \\
\text { families, those with disabilities, those with } \\
\text { mental health concerns, and those in fuel poverty, } \\
\text { pre-existing vulnerabilities unaddressed (relating } \\
\text { to poor quality housing, structural exclusion } \\
\text { from the best deals within the energy market) }\end{array}$ \\
\hline
\end{tabular}

Source: Authors

For the German solar transition, a range of distributive issues were discussed. These centered on coal miners and nuclear power workers losing jobs, and an uneven access to the Feed-in Tariff (FIT) ${ }^{2}$ — especially for those who do not own property. Germany has one of the lowest homeowner rates in Europe, with the share of owner-occupied homes at $51.4 \%$

\footnotetext{
${ }^{2}$ The German Feed-in-tariff (FIT) was introduced in 2000 and provides a guaranteed income for renewable energy producers over a period of 20 years. For more detailed information on latest FIT rates, see for example Fraunhofer ISE 2018.
} 


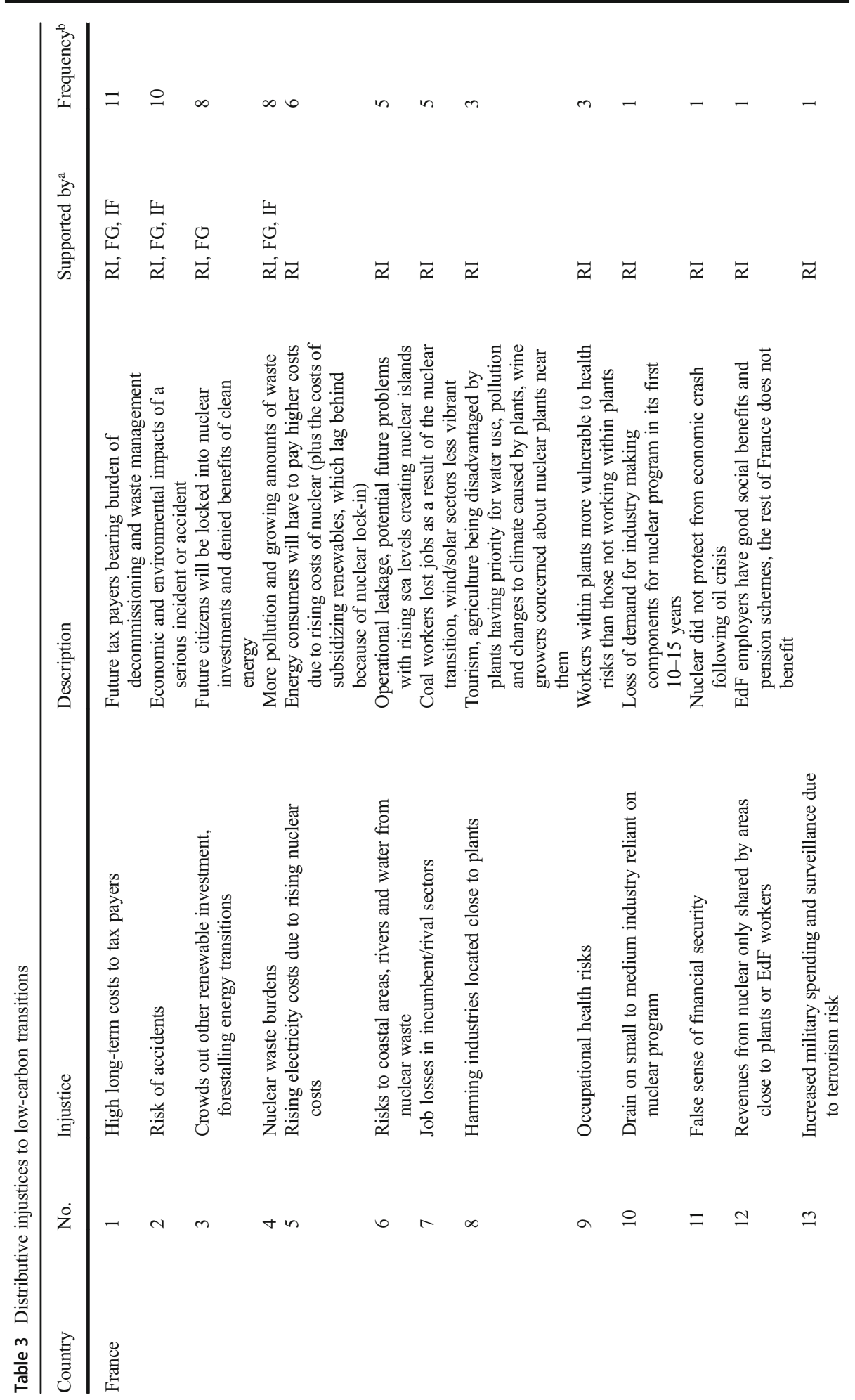




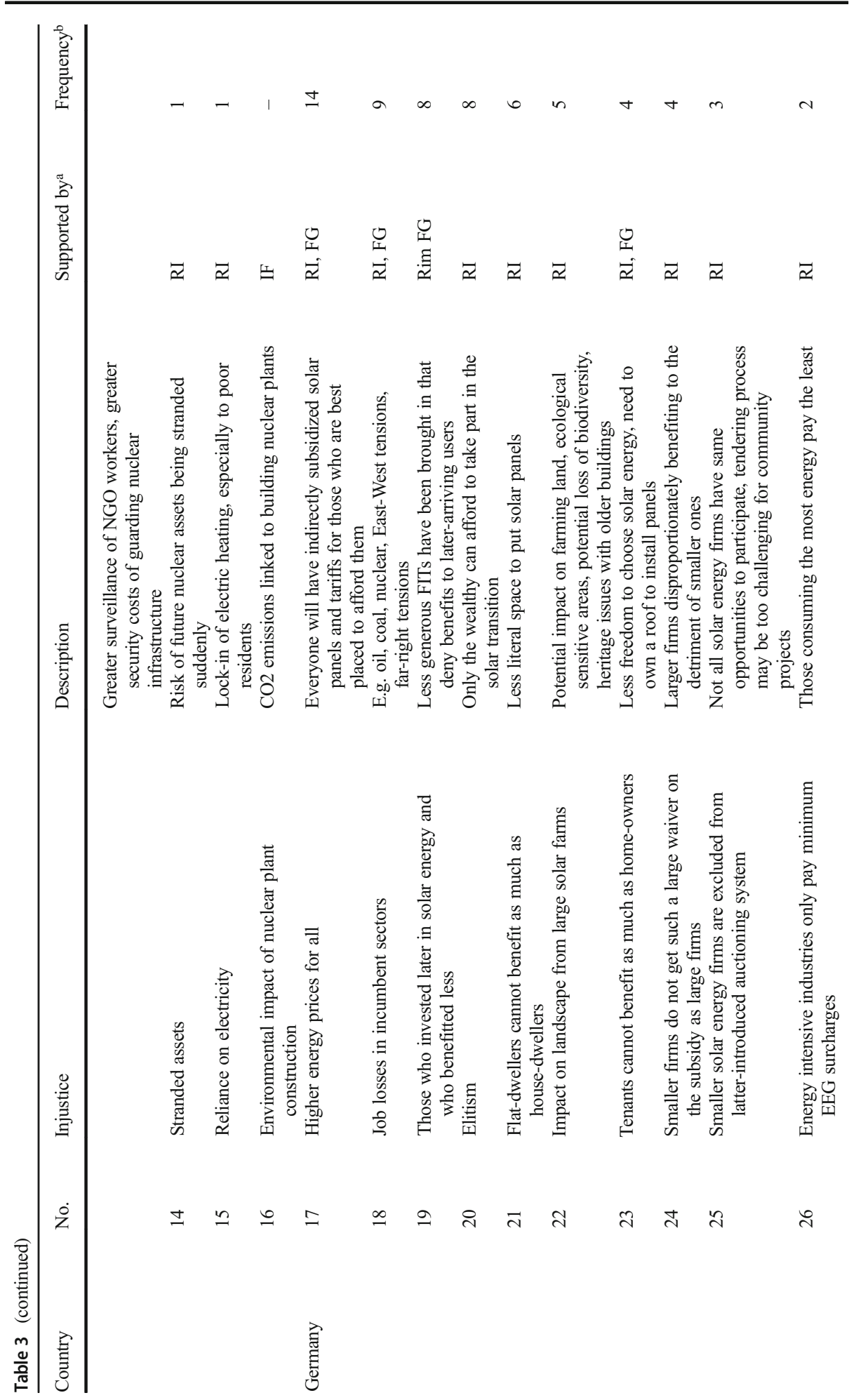




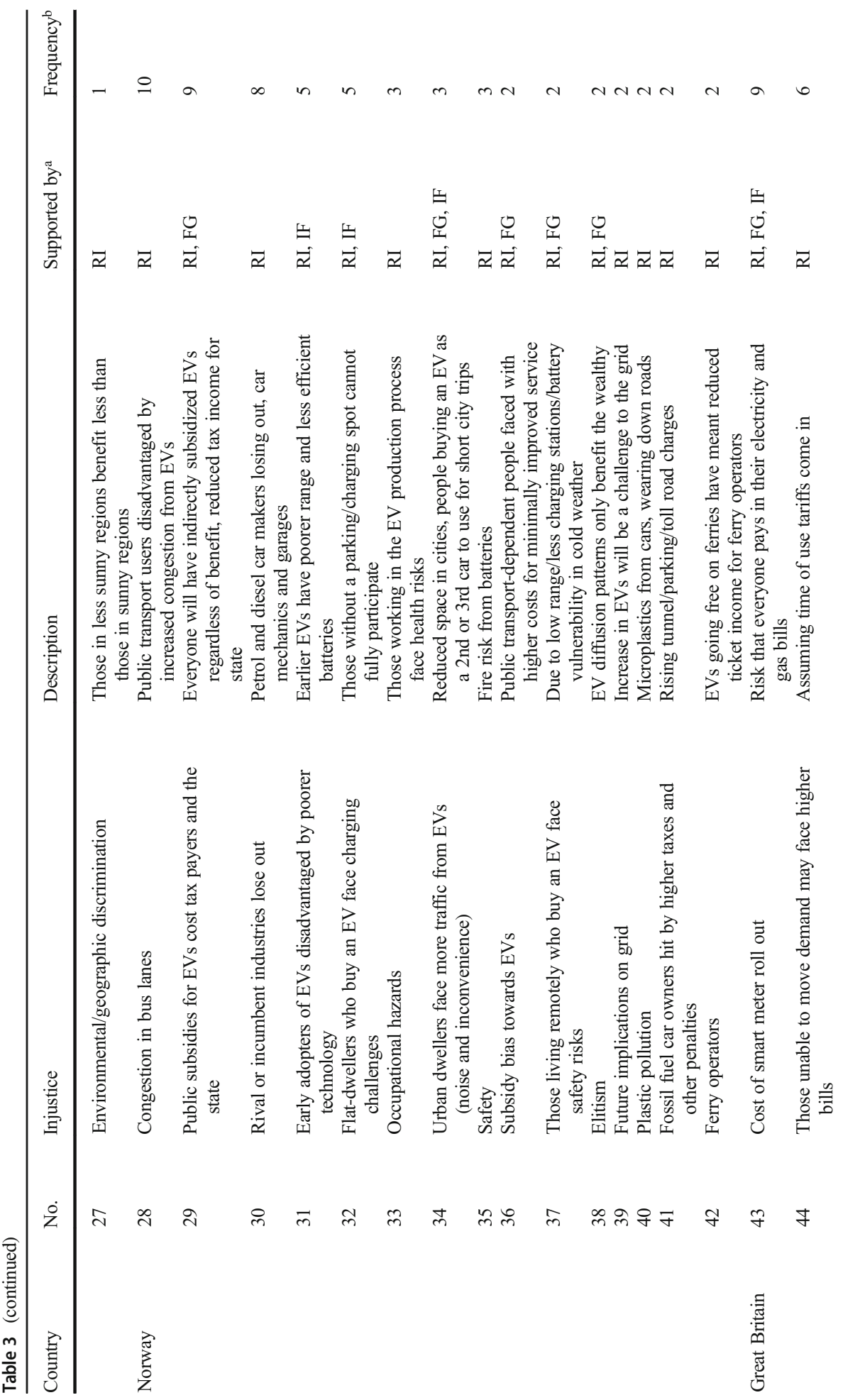




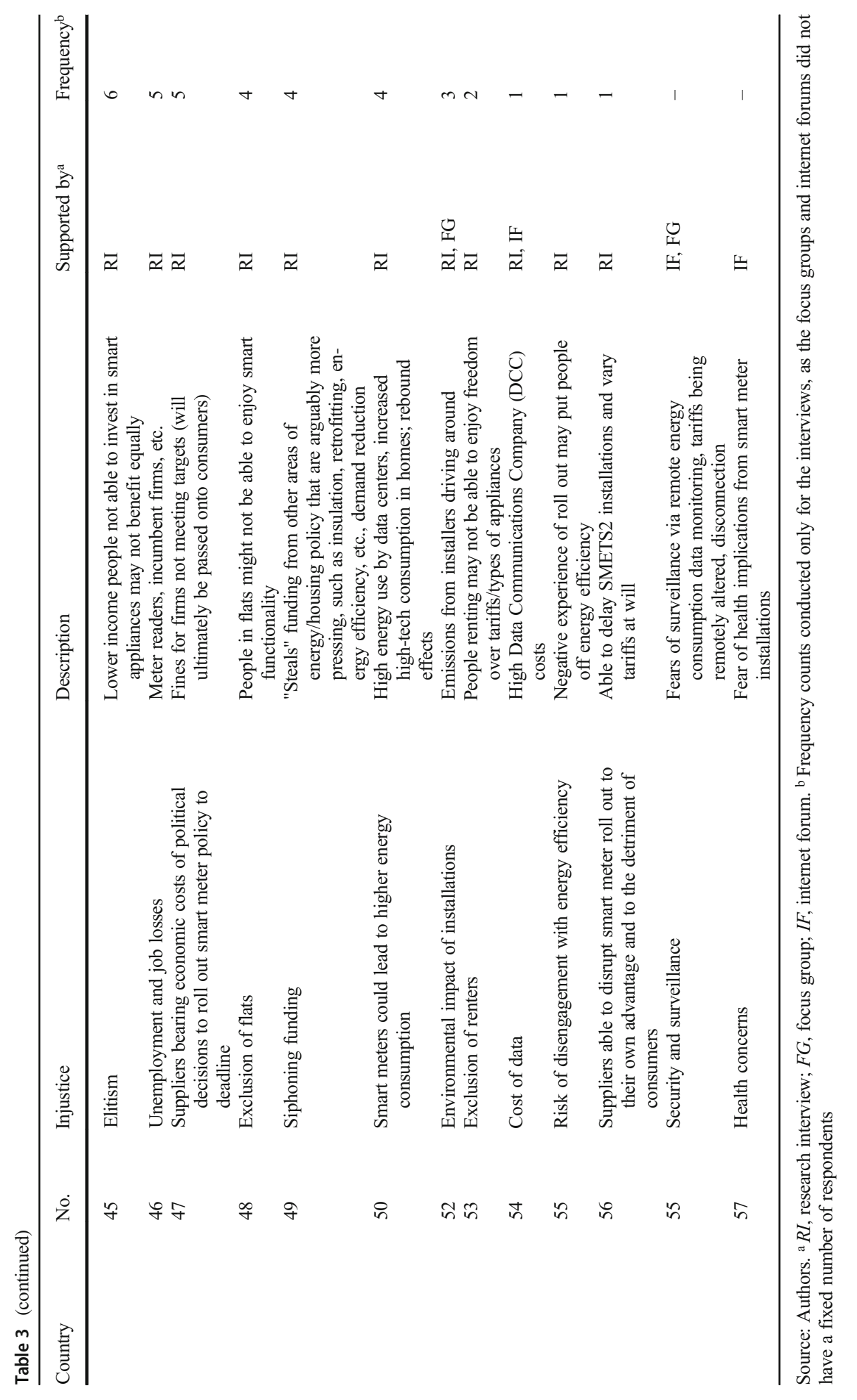


(Eurostat n.d.). As G005 noted, "now, because of solar energy, we basically have to close coal mines, which could make entire villages disappear in the next few years. For people in those communities, moving is a big risk, there are economic risks, social risks and environmental risks to these communities." One of the focus groups also underscored how difficult it would be to retrain unemployed coal miners, who usually suffer "temporary jobs and difficulty finding a new direction ... especially elderly ex-miners who have to take care of their families, they can't just go back to university." About 20,000 people are still employed in Germany's coal lignite industry, which accounts for $23 \%$ of power production. Jobs will therefore be lost as part of the country's coal phaseout, although an exact decision on has now been postponed until 2019. Meanwhile, subsidies for Germany's hard coal industry, which accounts for $14 \%$ of power production, are set to be phased out by end 2018 (Wecker 2018). Although G008 emphasized that children would be winners from a decision to phaseout nuclear power in Germany made in June 2011, they nonetheless recognized that "in general, as the renewables transition speeds up, losers will be those who are negatively affected by the current renewable energy system. The entire nuclear industry is at risk ... because again, the renewable energy sector in Germany was the material basis for the nuclear phase out."

Multiple respondents discussed the exclusionary nature of the FIT for solar, with those owning homes (and able to access finance) benefitting most, and city dwellers who were renting their homes likely to be left out. As G001 emphasized, "you don't see solar panels in Berlin, because very often the landlords who own the houses in Berlin, have no interest in putting up solar panels, because it's relatively small roof space. It's added difficulty and why should they do it and then supply cheap power to their tenants. The tenants can't put up solar panels because they don't own the roof. It's the landlord-tenant trap that makes it very difficult in cities to put solar panels on. As a consequence, most of the solar panels are in suburbia and rural communities." G005 suggested that "for me the justice issue is about local people who cannot afford to be part of the transition... this could likely mean an increase in inequality in regions, with a bigger gap between some prosumers and those left behind." Although we could not verify the numbers, G005 even estimated that as a result of these exclusions, "there is at least of half of the population in Germany who do not have any free capital which could be invested in a rooftop panel." G006 added that "some people cannot afford to install a solar system themselves because they are not the owner of a roof or house. But they have to cover the cost of the FIT." Germany has some of the highest energy prices in Europe, partly due to renewable energy support being levied on consumer bills (Heptonstall and Gross 2018). In 2018, the renewable energy surcharge accounted for 23\% of consumers bills ${ }^{3}$ (Clean Energy Wire 2018). Drawing attention to the geographical dimensions that could also contribute to exclusion, G009 stated that "Even if you own your own home but it faces north, or you have an apartment on the second floor or a 4 story building and you just can't get everyone in your building to put solar on the roof. So, you are locked out of being able to invest, at least within your own premises, but yet you have to pay the cost impact via the grid." This has meant that in cities, solar diffusion can be concentrated among larger community centers or offices (such as in Fig. 1), in suburban homes, and in rural areas within wealthier homes or regions.

\footnotetext{
${ }^{3}$ The renewable energy surcharge is a fee which has increased the most in German electricity bills since 2006, up from 0.88 eurocents in 2006 to 6.79 eurocents in 2018 (compared to grid fee for example which has increased from 6.93 eurocents in 2006 to 7.27 eurocents in 2018). Electricity costs were 29.42 eurocents per kilowatt hour in 2018 (Clean Energy Wire 2018).
} 


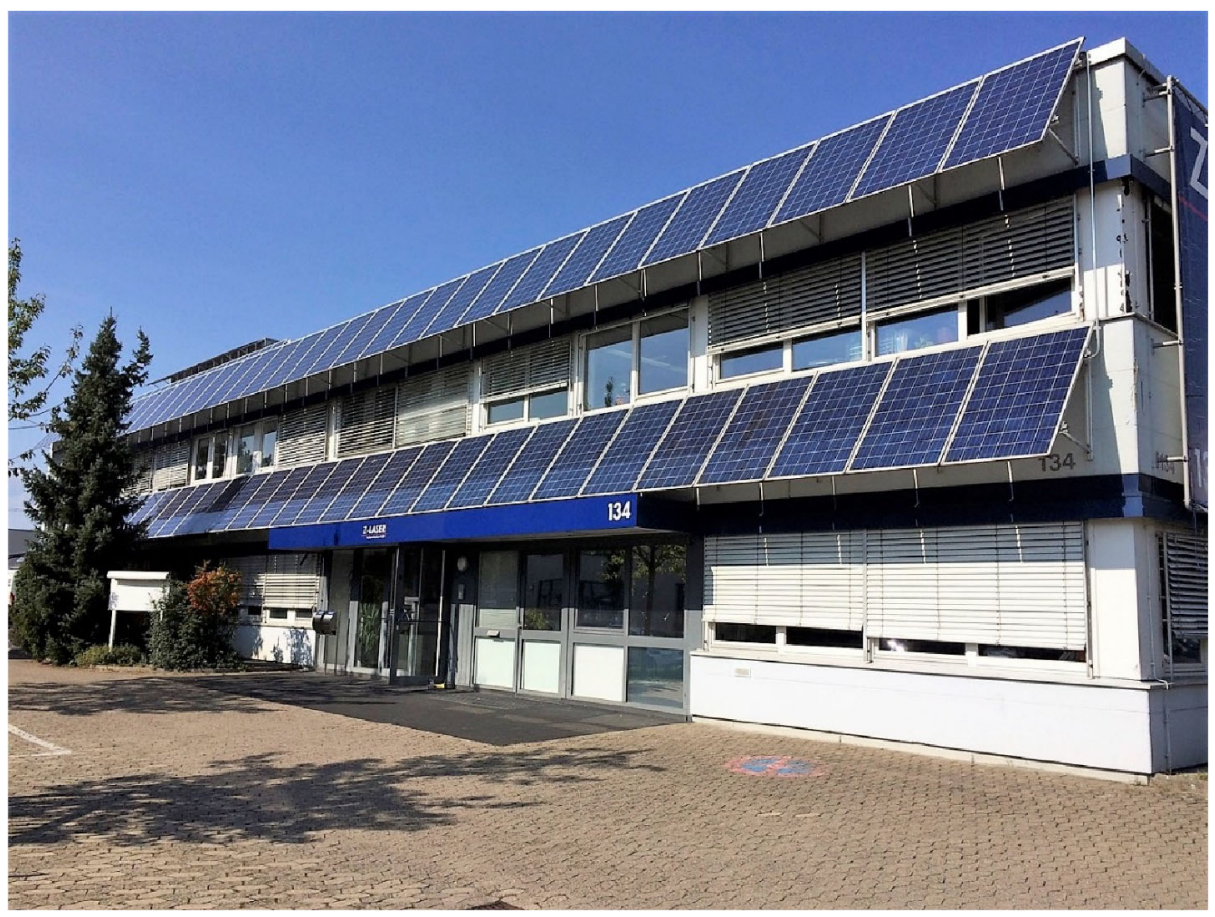

Fig. 1 Building integrated solar panels at the Intelligent Solutions in Light Offices in Vauban, Germany, September 2018. Source: Authors

Our data on Norwegian EVs led to the identification of a variety of distributive injustices, with three notable groups of possible losers, including those who cannot afford new cars, bus travelers, and ferry operators. Currently between 5 and $6 \%$ of cars on Norway's roads are EVs, which is set to increase significantly in light of the government's objective for all new cars to be zero emissions from 2025. N002 explained that the EV transition "is disadvantageous for those who don't have money to buy a new car or even a used EV ... people on low incomes are excluded." N005 explained that, "One important group losing out is the public transport users in those areas where there are bus lanes and where there are so many EVs that the buses are delayed ... Bus travelers are among the possible losers." Others focused on ferry operators, with N001 noting that "it was standard policy for many years that EVs could go on ferries free of charge, even now they can travel at reduced rates." N004 added that "some of the ferry companies have been delivering red numbers because of so many EVs, there is a worry some are going out of business."

Similar issues of exclusion and distribution arose in our discussion of British smart meters, some of which were echoed in a recent report by the UK's National Audit Office (NAO 2018). GB005 stated, for example, that smart meters, homes, and grids are creating a divide between those who adopt smart meters and systems, and those who cannot or do not, but still pay for the supporting infrastructure. As they explained, "at the moment, Ofgem are doing something called targeted charging review, addressing how people pay for network electricity costs, and one of the concerns is that as you have more households being more prosumers, generating their own electricity, and potentially having storage, they're basically not buying as much electricity from the grid. They are then not paying as much toward their network charges. So 
people who are still on the basic system may have to pay more to cover the issue, which is a fairly serious issue." GB008 even explicitly framed this in the terminology of distributive justice, stating that "I do think there's a tension between reducing carbon across the board with smart meters and distributing the impacts of that unevenly. You have people who are already not using enough energy for their wellbeing continuing to do so." Those in the internet forums framed this in terms of how smart meters could lead to higher prices for all customers, suggesting that "smart meters do not result in cheaper bills for all consumers, it is the exact opposite ... consumers have been and will continue to pay higher bills to fund the entire $£ 11$ billion smart meters program, with no guarantee of seeing any savings in the future." Another distributive justice issue centered on the risk of increased surveillance, with respondents in the internet forums and expert interviews highlighting the risk of remote disconnection of energy supply_-by either suppliers or landlords. In the focus group too, smart meters were considered as a potential surveillance tool, with respondents saying that they thought energy companies could "track what you do." A final distributive element was traditional meter readers losing their jobs, as GB007 suggested. Our respondents suggested there could be as many as 10,000 of these employees that could lose their jobs if fully digitized and automated smart meters were installed in all homes. Figure 2 shows one such meter reader in London.

Our results therefore show a range of distributive justice issues across all four cases, notably focusing on the unevenness of how costs and benefits are shared, and highlighting how exclusion can be unexpectedly prominent in these transitions.

\subsection{Procedural justice}

Our material led to the identification of 13 procedural injustices across the four transitions (Table 4).

French nuclear power is widely considered to have been predicated on an authoritarian style of decision-making that excluded opponents from planning and policy discussions. F001 exhorted a "nuclear oligarchy and a sense of disempowerment that comes from that, because a very small number of people really hold the reigns." F003 pointed out there was no transparency or national debate "involving citizens and in asking them where they want the limited funds for energy to go. Is it in making the plants safer or renewable energies? And even though EDF is private now, the state still has $85 \%$ of the shares." While some respondents acknowledged that there had been historic consultation on the nuclear issue, others stressed that it has effectively been "consultation without really taking into account the results of the consultation" (F003). F004 opined that those opposing or questioning nuclear were invariably not being heard, with critics practically excluded from public life: "for decades you would put your career at risk if you ever spoke against the nuclear consensus ... nuclear in France has had a very non-democratic character in nature ... nuclear power is intrinsically centralized, heavily planned, and therefore much contrasting with community interests and plans." F007 suggested that even though "it's less opaque and centralized than it was, there is still more to do, it has been a very expert-led process." F012 remarked on the symbolic physical exclusivity of nuclear that often accompanies the practical political exclusion: "nuclear projects are in a security zone, they don't allow for participation. Under the code of defense, you have fences, you don't have access to information ... the nuclear transition was decided without citizens." F014 meanwhile stated that the decision-making process is closed and "EDF has the key to power along with their cadre of economists and engineers in the Corps des Mines who plan the grid in a centralized way of thinking that is much embedded in the thinking of the nuclear class." 


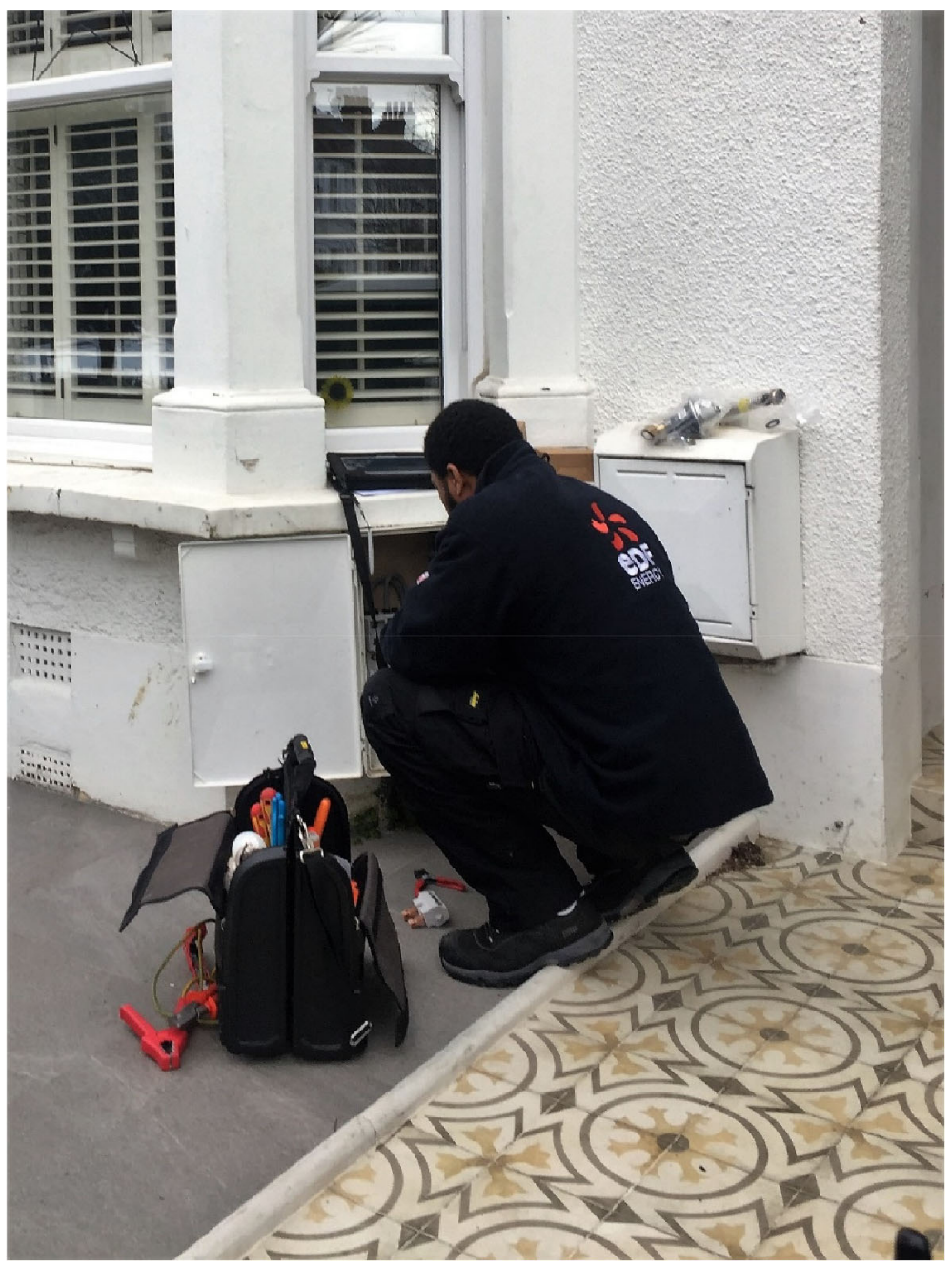

Fig. 2 A manual meter reader for EDF Energy in Greater London, February, 2019. Source: Authors

In Germany, respondents were not as harsh about procedural justice issues related to the solar transition, but still raised sobering concerns about planning processes, especially the capture of policy by industrial interests and a corresponding (and allegedly intentional) slowing down of the transition. G004 cautioned that within German planning and policy as a whole, "there's been a tendency to follow the interest of large companies and so to say traditional industries, rather than follow the voice of environmental NGOs or people." As a sign of this, G008 noted deliberate, visible attempts to slow rather than accelerate solar adoption in light of the caps put on renewable energy production in recent years: "the German policymaking process is totally corporatist ... the current government has been slowing down on the expansion of renewables since 2013. It's a government composed of Social Democrats and Conservatives. Social Democrats are basically driven by the coal miners' union and the Conservatives are driven by their allies in business. None of them want a renewables transition, by and large. Fundamentally the transition is working in the interest of industrial 


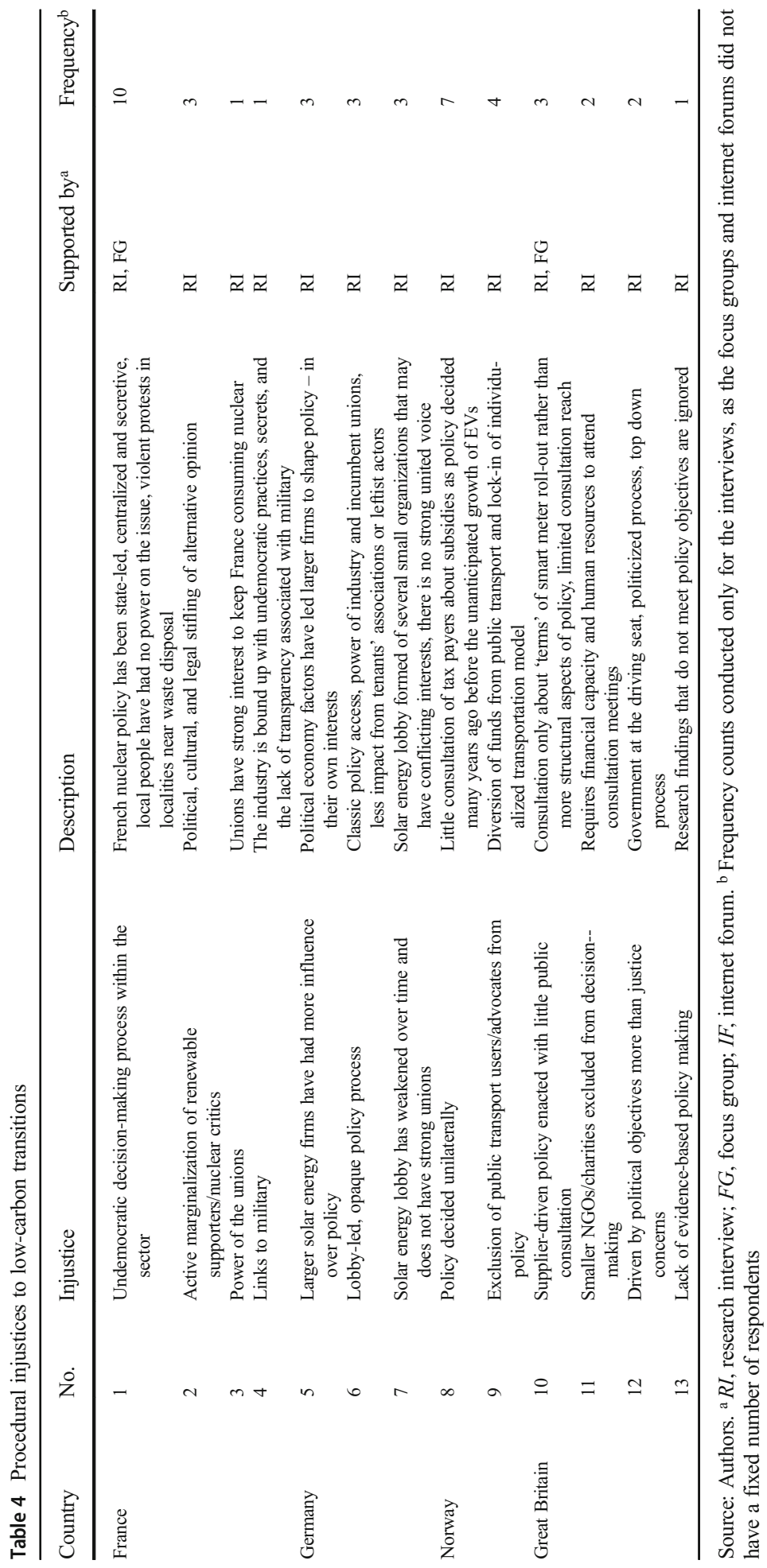


trade unions, particularly the mining unions and big electricity companies ... They said, in order to protect the renewables energy transition, we have to cap the expansion of renewables. Which is madly Orwellian. In order to have more renewables we have to have less renewables." Consequently, G008 concludes that "it is the big companies that successfully lobbied for exemptions from the FITs. Because by doing that, they have increased the prices for final consumers." G006 commented that such a planning system has created unnecessary barriers to entry and hidden costs that benefit incumbents and work against smaller systems. They stated "Today, for small systems, people who are operating a solar system have to pay some fees which you normally pay if you buy electricity from a utility, even though it is produced from your own system. For example, a supermarket which wants to get panels to power fridges, but it has to pay a fee to the utility, and this electricity is not going to the public grid. Such a barrier makes it unattractive to install solar on businesses in the tertiary sector or enterprises ... There are many other examples in this recent law on solar which from our point of view don't make sense." G014 added, "People who have a lot of political and economic power, they still fear the solar transition, and the government is really cautious that they are accelerating it too much. They want to have a slow change or slower change."

Procedural issues for EVs in Norway arose out of our material as well, including issues of fairness (the fact that e-bikes were excluded from subsidies and waivers) as well as of perceptions of a planning bias towards motorized cars. N007 argued, for example, that although "There are some people using e-bicycles and are fighting for cyclists' rights, these groups note that it is unfair that EVs drive without paying and have all these benefits such as free parking, and when they come on their bikes they have trouble coming through and also congestion, but you don't have benefits given to e-bikes." N014 critiqued Norwegian planning for still promoting individualized automobility, cautioning that "it is extremely important not to portray EVs as a solution to everything and to have an equal or even more investments in other, even better ways to travel. Supporting policies for public transport, walking and biking have to be the first priority and ensuring that cars that are used should be limited to the trips that you actually have to take by car. Currently, they are not."

With respect to procedural justice issues relating to smart meters in Great Britain, respondents mentioned a notable lack of public participation, as well as unjust tactics being used by suppliers to pressure or mislead people into adopting meters. Several respondents emphasized what they saw as the political nature of the program, framing it as being driven by political objectives rather than social goals or programmatic efficiency or inclusiveness. Although their statement can in fact be seen as evidence of such politicization, GB003 stated that "the smart meter program is not one being delivered by industry, independent of government. Unfortunately, government is very much at the driving seat, so it is heavily politicized. So a lot of the decisions that have taken place in the program wouldn't have been taken by business, which is trying to roll out an efficient program... so you keep going even though you know it's not the best thing for the program." GB005 added that "it feels like a very top down policy space... BEIS have been given this deadline, and the suppliers have been doing what they can to meet that deadline, and consumers are having to muddle their way through it." GB007 observed that the rollout had got to a point where program managers even ignore contrary data and advice, saying "the smart meter program hasn't been too inclusive. They made up their mind that they wanted to do it, and just rolled with it ... Even though policy framers might say the policy has responded to people's needs, the framings offered in the policy development phase during consultations may have been designed to give consumers limited options." This notion of the suppression of data also arose in the internet forums, whereas also reported in The Guardian 
(Hopkins 2018), a respondent alleged that "Ofgem employees have raised concerns about the smart meter roll-out process, and Ofgem are fighting to stop them revealing those concerns." GB009 reflected that "I wouldn't describe it as participatory at all... The discussion between the government and the energy companies at the start of the roll-out was narrow, I don't remember other parties particularly being involved." The internet forum participants added that policy was driven by "clueless governments" with "the public never being asked."

These concerns about process related to the smart meter program were coupled with concerns about unfair and misleading tactics used by suppliers and companies. According to our focus group, one respondent claimed that "my son is being held to ransom because they're saying 'if you want to go on this tariff, you have to have a smart meter installed', which is not true ... I feel a bit conned really." In the internet forums, respondents similarly mentioned how smart meters were being installed against people's will, with the program described, perhaps hyperbolically, as "a total con devised to create a demand for smart meters where it does not exist ... from now on they will have to be installed despite of protests from consumers." It is, in other words, poorly procedurally governed. All of these issues could become more acute because of pressure to compete the rollout. As GB002 warned, the program delivery had not been designed to allow for wider participation: "because of the time-line, there is a real risk that you won't be involving consumer groups, or the necessary parties, as much as you should be involving them."

These procedural injustices show that even in democratic societies, open access to policy and decision-making does not happen automatically. Our analysis demonstrates the closed nature of decision-making in the French nuclear case, and the lack of public participation, both in decision-making and subsequent rollout of the smart meter program, in Britain. While interviewees were more positive about procedural issues in the German and Norwegian cases, even they also observed injustices in the form of corporatist lobbying power in the future decisions for solar energy in Germany and a bias towards incumbent mobility options in Norway.

\subsection{Cosmopolitan justice}

Our material led to the identification of 18 cosmopolitan injustices, shown in Table 5.

For French nuclear power, cosmopolitan justice issues centered on uranium mining and exports of nuclear equipment to countries with poor safeguards. F011 for example stated that "in Niger and Kazakhstan, there is the buying of uranium, the conditions of workers, and the political systems, that is a justice issue," as also discussed in Graetz (2014). Other respondents focused on the ever-present risk of nuclear accidents, which F001 suggested was putting Northern Europe at the risk of "nuclear pollution". F004 meanwhile claimed that accident risks also threaten "communities living near the French borders" such as Belgium, Germany, Luxembourg, Italy, and Switzerland. F007 articulated this justice issue most clearly when they stated their opinion that a nuclear accident would have a devastating environmental and economic impact beyond the French borders: "From an environmental justice perspective, a small country like Luxembourg could just disappear if Fessenheim has an accident! Belgium too!' F007 also made the link between French nuclear exports and poor safety standards in less democratic regimes such as China and Russia, where they suggested that nuclear expansion could represent a "disaster" where international authorities may be unable to enter those countries and examine whatever problem had arisen. The cosmopolitan injustice of accidents came up in the focus groups as well, with respondents noting that "French nuclear reactors are 


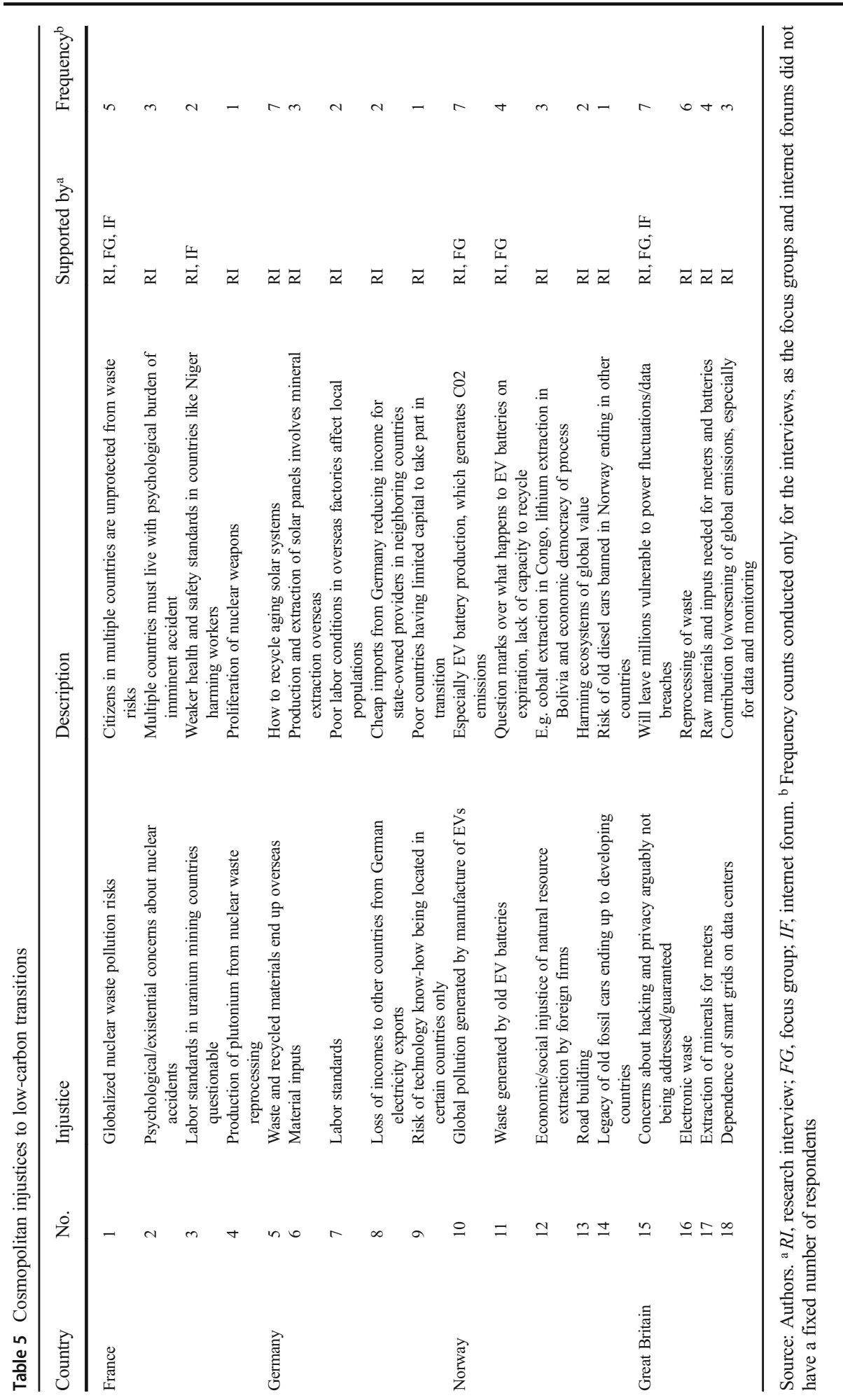


not being maintained to be safe, they have cracks," they present "immediate ecological risk" of an accident, and that "the safety issue is not being solved."

In Germany, respondents discussed raw materials, overseas manufacturing, and waste issues as pressing cosmopolitan justice concerns. G004 summarized this range of issues, suggesting that "you have to question where Germany gets its solar modules from, where are the resources such as copper and raw materials coming from. That has an impact on the countries where these raw materials are extracted, and working conditions for people working in the countries making solar panels ... In China, we don't know under what conditions workers manufacture the models."

In Norway, cosmopolitan injustices also centered on materials, waste flows, and overseas industrialization processes that are needed to produce EVs in order to satisfy demand. N001 noted EVs' requirement for lithium and cobalt, which are sourced from the Democratic Republic of Congo (cobalt) and Chile, Argentina, and Bolivia (lithium) (Azevedo et al. 2018). Another interviewee cautioned that "child labor" may even be used in some of these facilities. N006 reflected that "There are concerns with battery production. Scarce materials, terrible working conditions for people in mines in the Congo where they get cobalt from. And the disposal of the batteries at the end. There is a risk that this leads to environmental disasters somewhere else. We can drive around in clean cars in Norway only by exploiting even more poor workers in third world countries than we do today." In our focus groups, respondents too discussed the high environmental impact of manufacturing EVs, with one participant making a statement that, if true, would clearly undermine the low-carbon credentials of EVs: "because the emissions are higher in the production of an EV compared to a regular car. Because of the batteries. I read that you have to own an EV for 5-7 years $(75,000 \mathrm{kms})$ before the two cars became equal". As a result, N004 suggested, "EVs only make Norway green because they are produced somewhere else."

In Great Britain, respondents again emphasized waste streams associated with the manufacturing of smart meters (and in-home displays) as well as afterlife issues such as recycling and electronic wastes and carbon emissions. However, there was a general perception that these manufacturing and waste disposal processes were fairly mysterious, with most respondents admitting that they had no idea where smart meters were made or how the old meters would be disposed of. GB001 for example speculated that "Smart meters involve a lot of 'stuff'... The materials impact could be considerable. And how much are you relying on metals from war torn countries?" GB008 questioned the environmental and social burdens of manufacturing smart meters "outside of Europe," whereas GB012 critiqued the roll-out as "resource intensive." GB003 commented on the negative "carbon footprint" of the program, not least due to the fact that the distribution and delivery of smart meters is being carried out by fossil-fuelled trucks.

Our analysis shows that cosmopolitan injustices were identified in all cases, and they largely centered on globalized supply chains, sourcing of materials, and waste streams.

\subsection{Recognition justice}

Finally, our material identified 33 recognition injustices across the transitions depicted in Table 6.

In France, nuclear power was credited with contributing to the rise of a sub-class of poorer households whose dependence on electrical heating (a by-product of the electricity-centric vision that accompanied nuclear energy in France) had trapped them into higher prices. 


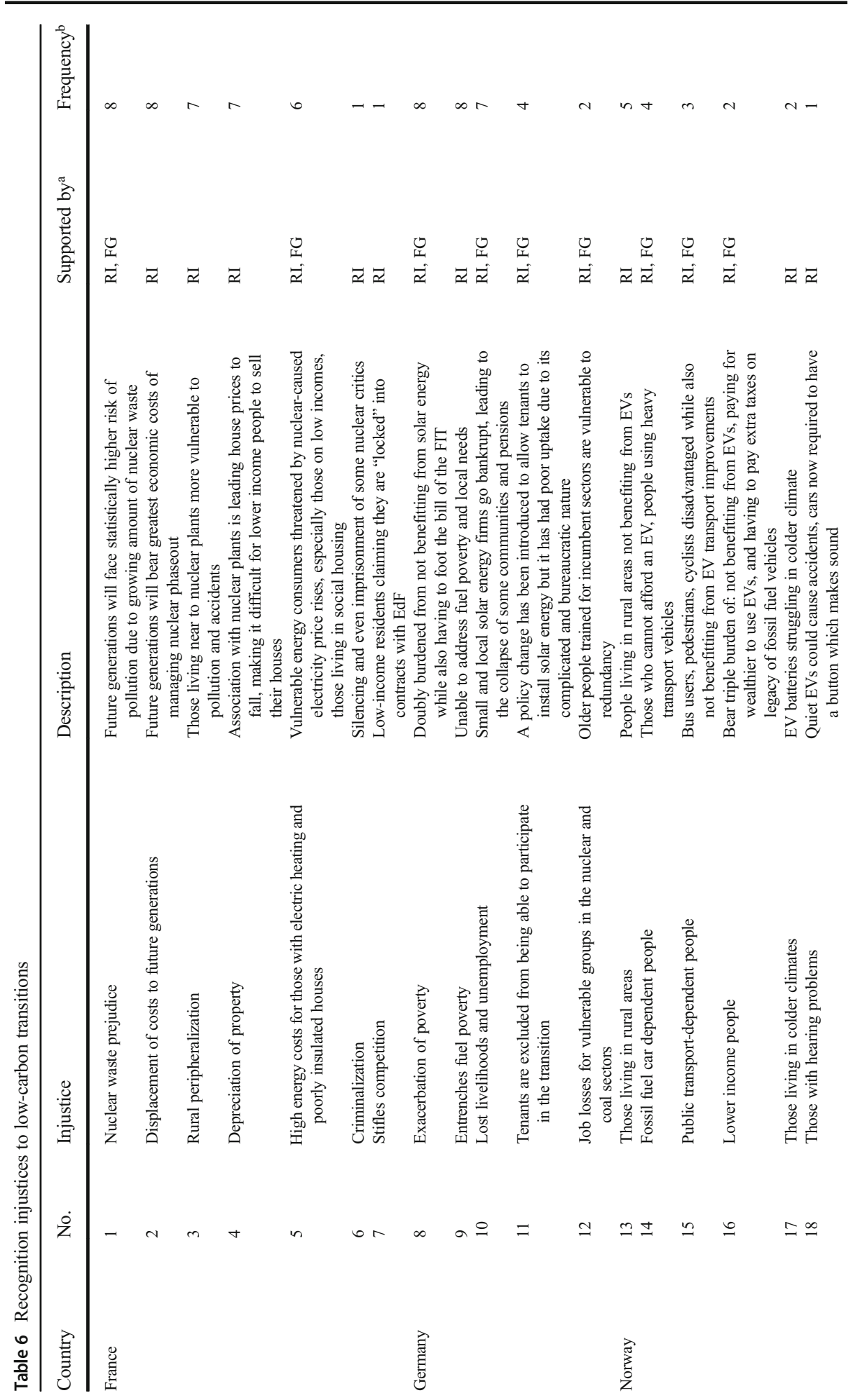




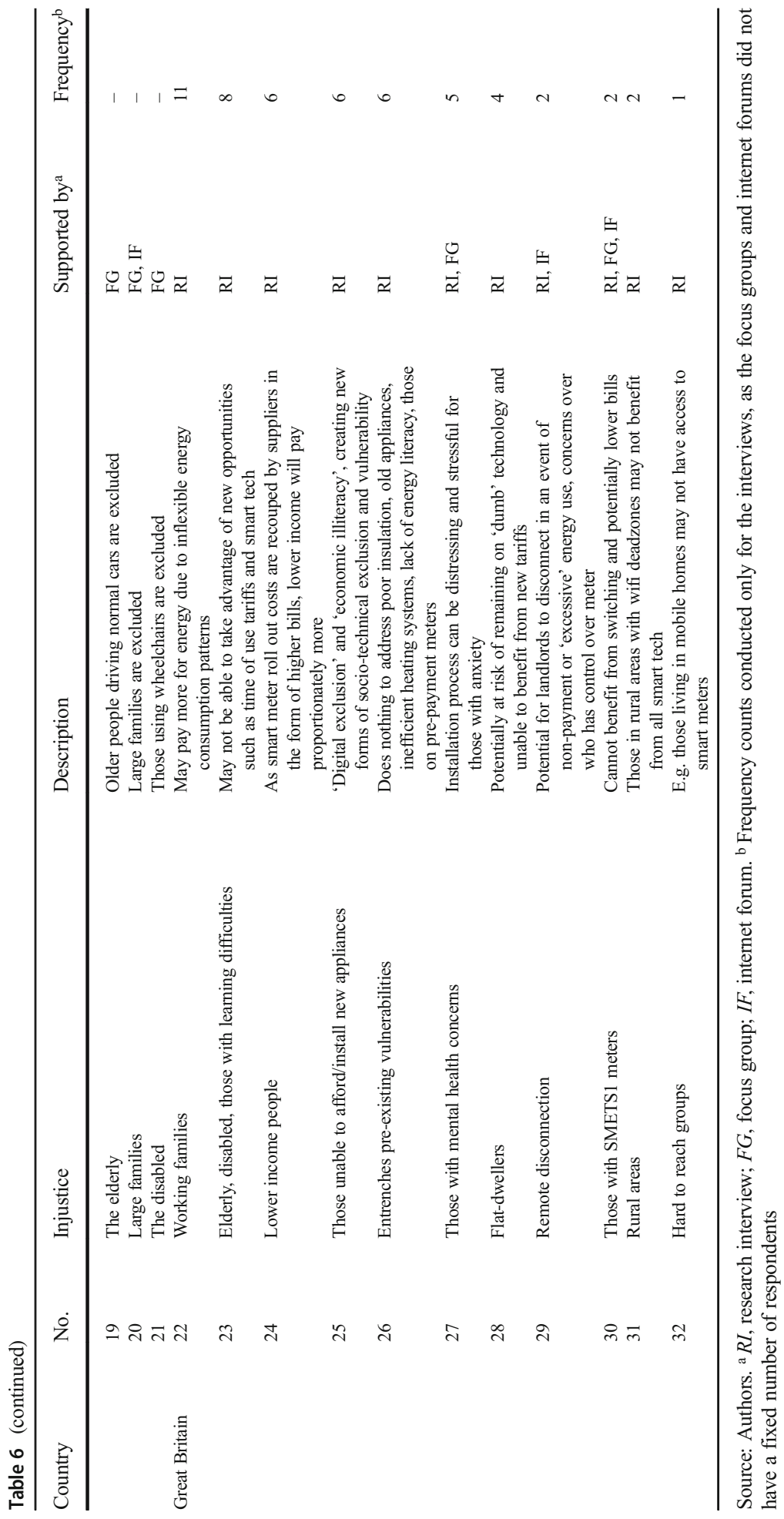


Thirteen per cent of heat is still supplied by electricity in France, which is higher than in most European countries (Eurostat 2018). As F003 explained, "part of the nuclear vision for France was an all-electric society, including heat, but this was only okay when electricity prices were really low ... People vulnerable to high electricity prices are owner-occupiers in rural areas, old people, who have lived in their home for years which is not insulated, low income people living in private sector apartments, and single mums with children in urban areas." Indeed, this inefficiency and vulnerability was literally built into the French nuclear electricity system, with F006 noting that "there was a point in the 1980s where there was a surplus of nuclear energy and the question was what to do with it... an intensive policy of electric heating with providers supplying households with the cheapest heating devices. This led to households on low incomes bearing the costs of inefficient heating. The owners took the most basic equipment, what EDF engineers nicknamed 'bread toasters', which has a very low efficiency and has resulted now in people in social housing having to pay high electricity prices." F016 endorsed this interpretation, arguing that, "the fact that electric heating was pushed was not a good decision for the poor, because many now struggle to pay their bills."

In Germany, the solar transition was critiqued for having an unjust impact on poor households, including the elderly or single mothers. As G001 argued, "there are classes of people with higher electricity loads who are not benefitting at all from solar energy... I am talking about the part-time employed mother without a husband at home, with 4 or 5 children. She will have very high cost of running the washing machine and the dishwasher ... there are others, such as elderly people, who spend in excess of $20 \%$ of their total income on their electricity bills." Although this link is not universally accepted, G002 directly connected these instances of poverty and vulnerability to the FIT scheme by noting that "renewables are financed by the whole society during this system of a levy, that has to be paid by every consumer, but not every consumer has the possibility to take part actively in the energy transition and to have a financial return." G003 framed this as the "double effect" on poor people, stating that "Firstly, they won't have enough money to install solar systems on their houses and in many cases, they don't own a house. But secondly they have to pay the higher energy price."

In Norway, respondents discussed recognition concerns as relating to those with disabilities, single mothers, the elderly, and the rural poor. N014 suggested for example that "those with hearing problems, who are deaf, are vulnerable to EVs because they do not vibrate, they do not produce sound." A focus group participant mentioned how "oil executives driving EVs around Stavanger is a bit of an irony, but it becomes stark when one considers the single mothers who cannot afford EVs and must take the bus." Another focus group respondent mentioned how "older people used to normal cars are excluded from the transition as many will not be able to afford an EV." Multiple respondents meanwhile suggested that the EV transition has further marginalized the rural poor, given that such areas often lack adequate public charging infrastructure.

Finally, in Great Britain, respondents mentioned the possible negative impacts of smart meters on groups such as single-parent families, the elderly, those with disabilities, those with mental health concerns, and those in fuel poverty. GB015 stated that, "right now, smart meter technology is appalling for the most vulnerable people." GB016 suggested that "if you want to help the people who are vulnerable and you want to think of people who want to be more empowered and care about the environment, the smart meter program goes nowhere near that at the moment."

Our material identified several reasons for the negative impacts on vulnerable groups. GB001 explained that vulnerability was related to the proposed introduction of "time of 
use" tariffing: "the people who seem to be most under pressure to lose from the smart meter program are typically a single parent or two parents who are working hard and have children and pretty much all the family activity has to be channeled into a period between 5 and $7 \mathrm{pm}$. If via smart meters you introduce stiff charges then, then they can't really move it [energy consumption], because they're doing two jobs, children are young and have to go to bed." GB003 focused more on how smart grids have a built-in bias against the less educated or informed, or those in fuel poverty. In this way, they suggested smart meters may reinforce existing disparities in wealth: "with a smart meter, you could argue that the people who most need to interact with the in-home device are the least likely to. So, the ones with the lowest incomes are the ones that are least likely to understand what the in-home device is telling you. Because of the level of know-how and comprehension that they need to go through the different menus and understand what they need to do to change their consumption is difficult."

Others, such as GB006, framed vulnerability for the poor or those with mental health problems in terms of anxiety and stress, stating that "smart meters can be distressing. For those that use pre-payment meters, over half say that energy is a daily concern for them, so it actively causes anxiety. People with mental health challenges may struggle to engage with market." GB006 agreed and added that "the most vulnerable people will simply disconnect from a smart energy system. They just switch their energy off. We see people not using their heating, shrinking down until they're in one room in the house, and not using the lights. They sit in the dark and the cold ... Vulnerable consumers are losers of the smart meter program ... smart meters are incapable of responding to any of the root causes of that exclusion, which is poverty." Similarly, GB008 stated that "fuel poverty, households on low income, those with disabilities, and other vulnerabilities might be further compounded under the program."

In some cases, smart meter installations have allegedly even led to the forcible removal of inefficient equipment for safety reasons, leaving the financial and administrative burden of boiler replacement on poor homes or the elderly. As GB005 explained, "When smart meter installers come into the property, they have to do safety checks on appliances and gas appliances. We've seen quite a few cases where 20 to 30 -year-old gas boilers are legally condemned and therefore removed, so the household is left without heating supply." These range of potential impacts on the elderly are then clearly at odds with the smart meter marketing materials such as those in Fig. 3, which appear to indicate that the elderly will be major beneficiaries of the program. In other cases, smart meters can lead to disconnection and remote disruptions of energy service. In this regard, GB009 warned that "where you have landlords paying the bills, landlords are looking to use new energy technology to remotely control tenants' access to heat, so, setting heat to go on or off at certain times of day... because they're paying the energy bills... which is quite common in HMO situations ... you could see the same risk with smart meter-enabled products for managing energy remotely." The potential impacts suggest that smart meter marketing materials such as those in Fig. 3 may especially fall on deaf ears.

Our analysis therefore shows that there are several vulnerable groups who need to receive better recognition of the issues they, and others, face in low-carbon transitions. Those on low incomes were affected in all four cases, but most notably in Germany and Norway where people with limited incomes have had to bear the cost of subsidies of new programs while not being able - due to a lack of finance - to reap any of the benefits. Those with disabilities were also mentioned in multiple transitions (the deaf or those in wheelchairs and EVs, those with anxiety and smart meters) as being vulnerable and/or excluded. 


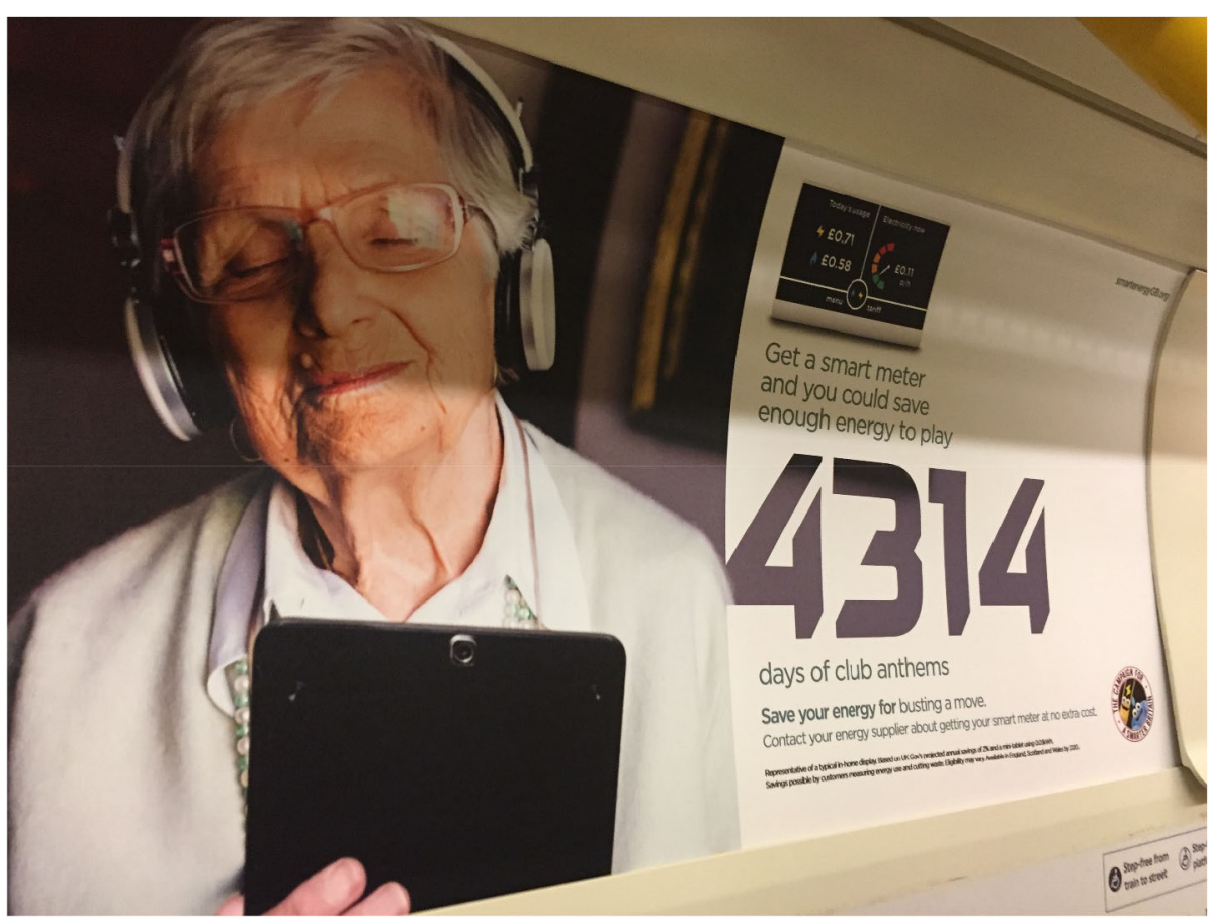

Fig. 3 Smart meter advertisement on the District Line Underground, London, November 2018. Source: Authors

\section{Policies towards more just transitions}

Although our first batch of questions focused on problems (framed as injustices), the final question focused on solutions, framed as policies to make each of the transitions more just (or less unjust). Thus, our material led to a compelling mix of actionable policy implications summarized in Table 7.

In France, respondents raised a variety of progressive changes that could be made to make nuclear more just. F004 emphasized the need for more explicit accounting of costs and a possible nationalization of EDF and a privatization of costs, noting that "There are talks about separating EDF's activities, nationalizing the nuclear fleet while privatizing all the non-nuclear activities." F006 mentioned "revising tariffs so that the poor and those on electric heat are not overly penalized." Other respondents mentioned making French planning more "community responsive" and "democratic," potentially with a "referendum" on the future of nuclear. F012 approached the problem from a different (and more hopeful) direction, noting that state control could also be seen theoretically as an asset, given that it imbues a democratic society with the ability to force the state to use its immense authority and power to implement positive changes: "The state in France has immense ability to control or change its energy sector, EDF still controls $85 \%$ of production, $100 \%$ of the grid, the transmission system, the client contract system." Interestingly, several respondents drew attention to the potentially disruptive influence of changes to EU competition law, which may erode EDF's economic and political power by outlawing the long-standing existence of the (subsidized) "political" price for electricity in France. 


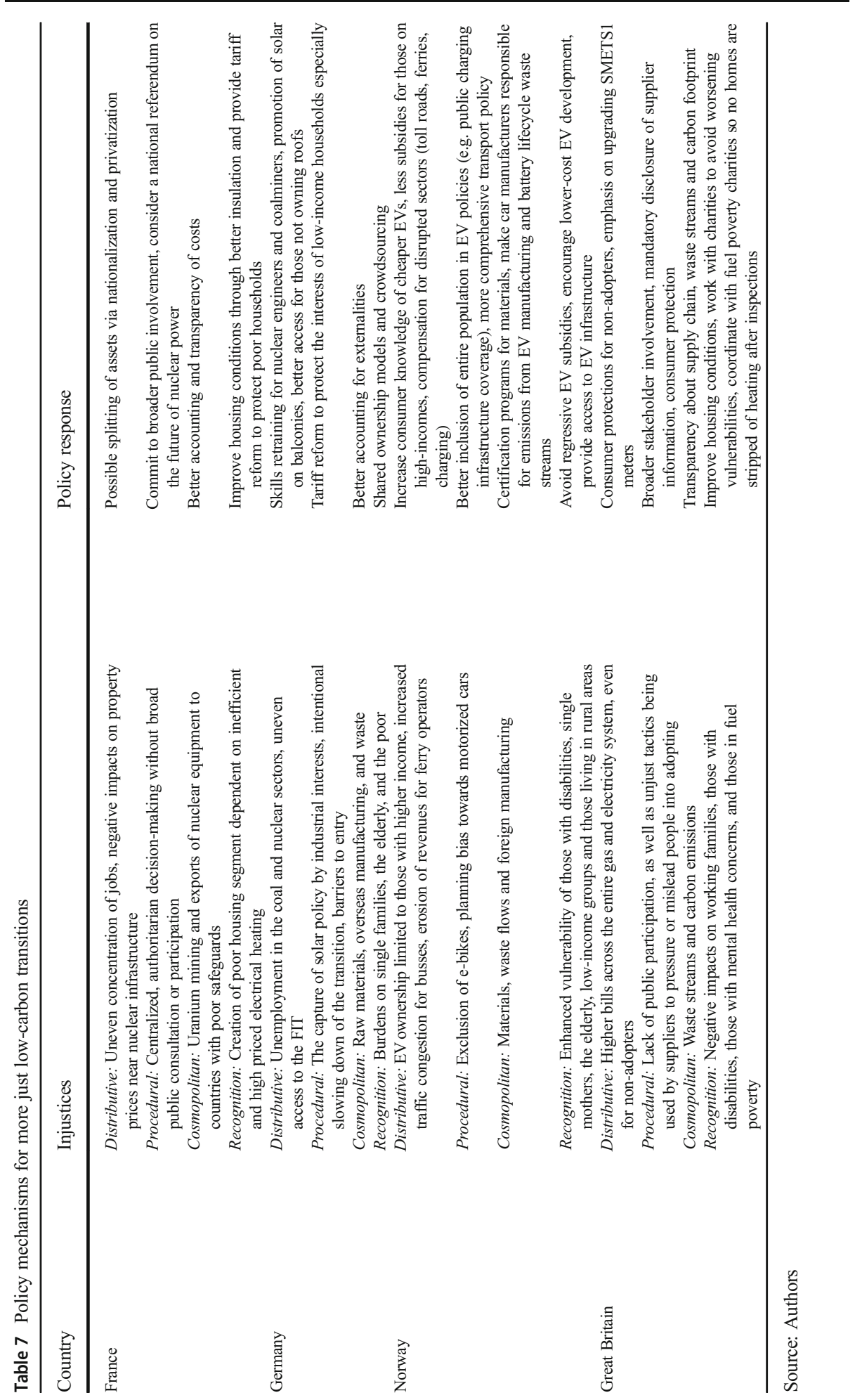


In Germany, respondents discussed broad changes in the policy framework to facilitate what G002 called "equal treatment, equal rights but also equal duties for every market participant across the whole system, taking into account externalities." G004 specifically discussed how to broaden participation in the FIT by focusing on options for low-income households or tenants, proposing that "we can offer a special provision for people who rent a flat to participate in owning electricity produced elsewhere on the rooftop of normal houses ... another option is to hang one or two solar modules on a balcony or a side of a house. There have been some breakthroughs recently concerning the technical and legal regulations concerning these balcony modules, as we call them." G005 focused on the "reskilling and training" for those who have lost their jobs, such as engineers or coalminers, whereas G006 mentioned offering incentives to "social housing companies" so that they are more "active in that market, which would make it more just and equal for everybody." G006 also discussed the promise of "shared ownership models" or "crowdfunding" where broad groups of people can invest in solar energy, not just those with homes or disposable income. ${ }^{4}$ This could be coupled with tariff reforms, giving electricity for free to those in need, with G008 suggesting "if you're looking at welfare recipients, I would reverse the way prices and electricity use correlate. So far you pay the most for the first few kWhs and then less and less and less, invert that. You have to make some kind of policy. And there were proposals on the table where you had a cheap or free guaranteed minimum electricity usage per person, say $1000 \mathrm{kWh}$ per person per year for adults."

In Norway, respondents emphasized the need for a more comprehensive transport policy that discouraged driving, encouraged cycling and walking, and sought broad public input. N007 said that "I think the main policies should be that we have fewer vehicles and the politicians have to fight for that. EVs should be an alternative for people who have to use the car, but should not be the main transport system in the city, and to and from cities." N009 emphasized that improvement in public consultation must be made so that they are more geared towards protecting the vulnerable; they stated: "when EV incentives are going to be taken out, we must have a voice on how it should be done." N011 meanwhile suggested that manufacturers be made responsible for recycling and waste issues, noting that "some automakers already mandate their own recycling, they take their batteries back. Perhaps this is the best approach, because EVs are so specialized. Governments around the world should demand that car manufacturers recycle batteries. Car manufacturers could take responsibility for the whole supply chain and since it's such a large valuable item that they are producing, it's reasonable to demand transparency in the supply chain." Other respondents discussed better planning procedures for charging infrastructure; adjustments to policy to better compensate those being disadvantaged, such as toll operators and ferry companies; and providing more information on affordable EV options.

Finally, in Great Britain, respondents highlighted the need for more robust policy mixes and a more holistic approach to energy injustice that went beyond purely technological solutions. Several respondents were particularly enthusiastic about initiatives in the area of housing that aimed at minimizing pre-existing energy vulnerabilities. GB001 argued for comprehensive policies for energy efficiency and housing, for example, and for prioritizing so-called dumb

\footnotetext{
${ }^{4}$ In 2016, citizens (renewables and farmers) held a $42.5 \%$ ownership share in Germany's renewable energy sector, the remainder being held by business, project developers, utilities, funds, and banks. The switch from the feed-in tariff to auctions has meant that large corporate players now are starting to dominate in terms of ownership (Morris 2018).
} 
solutions alongside the smart ones: "With so much emphasis on smart futures, and rolling out smart grids, you lose sight of the fact that for a lot of vulnerable people, their energy problems don't primarily need smart solutions at all. It's about decent housing, as it has been for decades... People living in poor quality, typically private rented housing need the overall standards of that housing improved... So, it's the 'dumb' stuff that still needs this attention ... otherwise it's not worth diagnosing the ailments because you don't have anything to treat them with." GB004 discussed the need for procedural changes and for an opening up of dialog, especially with regard to the disclosure of information by suppliers: "We need open dialogue between stakeholders, ongoing sharing of lessons learned, which happens in my experience between Smart Energy $\mathrm{GB}^{5}$ and suppliers and ourselves ... using research and other knowledge that suppliers have is the best way to mitigate potential downsides." Such information could in theory also account for waste streams and carbon footprints, and transparency in the supply chain. GB005 suggested that "we need to ensure that suppliers give referrals onto fuel poverty charities, which might be able to help with new heating systems, or the suppliers might be able to support vulnerable clients, especially when they are disconnected or see their boilers condemned during inspections with the roll-out." GB008 discussed the need for a broader harmonization of fuel poverty and smart meter policies, suggesting that "the carbon saving agenda needs to recognize that some people haven't yet met their right to sufficient energy to satisfy their health and wellbeing. The point is to make sure that everyone has equal access to energy, and once that happens you can reduce energy across the board, rather than repeating existing inequalities." GB012 mentioned that the current system is too skewed towards incumbents, and it thus needs more democratic community involvement: "the industry is set up to benefit the old stakeholders which are effectively the incumbents, .... we can't let them continue, and if we want to change it we're going to have to move it to a system with multiple distributed energy resources organized flexibly ... we also need legitimate and transparent decision making that puts customers truly at the center." Lastly, in the focus groups, the issue of better meters, upgrades, and replacements was broached, with a respondent saying "I'd like the government to say, we got it wrong, we'll come back and put you in a meter that is compatible to any energy company."

These policy options identified by our respondents provide further evidence that there is room for improvement in all of the four low-carbon transitions in providing more open and democratic processes in tandem with ensuring more equitable outcomes.

\section{Conclusion and implications}

Overall, our analysis reveals that although some of our respondents could not identify any injustices associated with our four low-carbon transitions, we extrapolated 120 distinct injustices on the basis of our interview, focus group, and public internet forum data. This disjuncture could indicate that many of these injustices are "invisible" and can appear hidden at first, which further demonstrates the need for energy justice approaches in analyzing lowcarbon transitions. Taking a simple frequency count, as the top panel of Fig. 3 summarizes, distributive justice issues dominated by type, accounting for almost half of all mentioned injustices. By case study, injustices were more evenly distributed with smart meters (34

\footnotetext{
${ }^{5}$ Smart Energy GB is the organization handling public engagement for the smart meter roll out: https://www. smartenergygb.org
} 
injustices) entailing the most, followed by nuclear power (31 injustices), electric vehicles (31), and solar energy (24 injustices). With this in mind, we offer seven conclusions.

First, the distributive energy injustices revealed by our interview data do not just relate to traditional centralized sources of supply such as nuclear power. We also see legitimate criticisms of community solar, smart meters, and electric vehicles. This implies that distributive injustices may be associated with more decentralized forms of energy at the micro dimensions of generation and consumption. In two of our cases, Norway and Germany, distributive injustices are most striking in how costs were believed by respondents to have been shared across all tax payers despite only a few, higher income groups benefitting. Such concessions in one sector have also had impacts on other sectors, as illustrated with Norwegian ferry operators reporting losses due to a high number of EVs traveling free on their services. In the more centralized case of nuclear power, French taxpayers will ultimately foot the bill for a nuclear legacy in terms of maintenance and waste management costs. While the costs of the British smart meter roll out are officially the responsibility of the energy and gas suppliers, there are fears that these will eventually be covered by raising consumer bills.

Second, the procedural injustices identified serve as a stark reminder that, though some low-carbon technologies may be more distributed and decentralized, they may nonetheless still be governed or managed in essentially undemocratic ways. For example, the arguably exclusionary nature of the German FIT for solar energy and the supplier-led smart meter roll-out in Great Britain appear to be generating injustices that might have been avoided under different governance approaches or policies. The centralized and secretive nature of state-led policymaking in the case of French nuclear power has meanwhile meant that there has been very limited access from anyone outside the official nuclear elite, resulting in a closed system that maintains the status quo, crowds out alternative energy imaginaries, and silences opponents. As such, decisions made regarding nuclear power in France are not likely to be based on fair representation and open participation. Therefore, procedural injustices such as lack of transparency with military links prevail in the French nuclear case.

Third, the prevalence of cosmopolitan injustices underscored the multi-scalar dimensions of energy injustice. Grimly, in all our cases, there were cosmopolitan injustices related to materials and waste and the impacts their manufacturing may be having across supply chains. In the Norwegian, German, and British cases, injustices such as poor working conditions and child labor linked to cobalt mining or rare earth minerals extraction were connected to the batteries and materials needed for EVs, solar energy, and smart meters. French nuclear power also has close links with the socio-environmental hazards of uranium mining and milling.

Fourth, low-carbon transitions are known to be disruptive and contested, but our analysis shows that this disruptive nature can have profound impacts on certain groups of people. The dimensions related to recognition justice show that transitions can create new vulnerabilities or worsen existing ones, especially among the poor, the rural, those with disabilities, those with mental health concerns, and large families. A real and troubling trend is emerging that lowcarbon transitions may be leaving some behind, especially those working within incumbent fossil fuel regimes. This suggests that research so rigorously identifying and calculating the cobenefits of low-carbon transitions be complemented with that looking at the non-benefits or dis-benefits, as well as their effect on vulnerable groups.

Fifth, and as the bottom panel of Fig. 4 indicates, qualitative commonalities exist across the transitions in terms of injustices that seem to recur independent of the case study in question. Whereas the top panel of Fig. 4 shows all injustices, whether they were 


\section{a. Top panel: simple frequency count by type and case study}
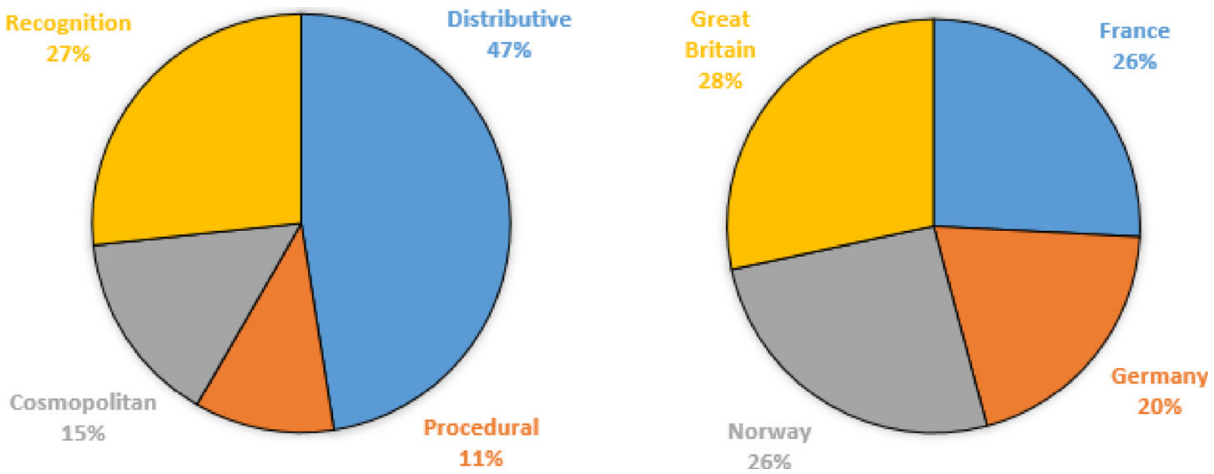

b. Bottom panel: qualitative synthesis by commonality

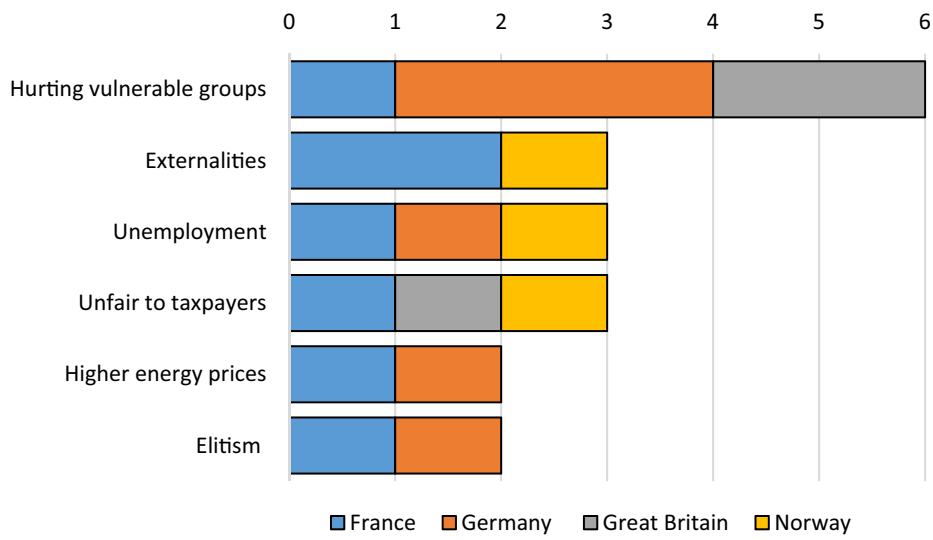

Fig. 4 Summary of energy injustices by type, case study, and commonality. a Top panel: simple frequency count by type and case study. b Bottom panel: qualitative synthesis by commonality. Source: Authors

mentioned by a single respondent or a majority of respondents, the bottom panel shows those that were most frequently mentioned by at least half of our respondents in each country (so by at least 8 respondents out of 16). Nineteen injustices met this criterion, which we then qualitatively organized into six categories (See Table 8 in the Appendix). The most common category included negative impacts on vulnerable groups, including working families or the elderly having to pay more for electricity or gas via time-of-use rates facilitated by smart meters; or those on low incomes in Germany having to subsidize the social costs of a feed-in tariff for solar energy that they cannot benefit from; or the risk management challenges nuclear waste will impose on future generations in France. The next three categories - with three injustices each — related to externalities, unemployment, and a burden on taxpayers. For example, our material discussed negative externalities from the French nuclear transition in terms of pollution from uranium mining and milling as well as the risk of a major safety accident; in Norway, the adoption of EVs has led to greater congestion for public transport in around the city of Oslo. Exacerbating job losses and unemployment were mentioned in France (locking out a renewable energy industry), 
Germany (renewables displacing oil, coal, and nuclear power), and Norway (petrol and diesel car makers and dealerships losing out). Burdens for taxpayers were also commonly mentioned for France (taxpayers were noted to bear the burden of nuclear decommissioning and waste management), Great Britain (taxpayers and consumers were said to subsidize the system costs of the smart meter rollout), and Norway (taxpayers were said to subsidize indirectly the tax breaks for EV adopters). The final two categories of injustices most common across transitions were higher energy prices for everyone, and the erosion of democracy and participation in favor of elitist policymaking, both mentioned for French nuclear power and German solar energy.

Sixth, although we have treated these four justice dimensions as distinct, and as mutually exclusive as possible, there are clear and compelling interlinkages. French nuclear power silencing nuclear critics is an issue of procedural justice that also intersects with recognition concerns about marginalized groups, when those critics represent the interests of the fuel poor or rural communities. The distributive concerns about the German FIT for solar become entrenched in national policy, making it a procedural concern as well, and when both distribution and procedure exclude vulnerable groups, it aggregates inequalities among sub-groups in ways that impinge on recognition justice. In Norway, the exclusion of public transport users and advocates from policy is a procedural issue, but one that can cement inequalities in distribution as well as the vulnerability of certain groups, a concern of recognition justice. Lastly, the potential for unemployment among meter readers is a distributive concern, but when it may impact particularly vulnerable communities, it becomes a recognition concern.

Seventh, and lastly, is that injustice is not inevitable. Our material led to the identification of at least 16 different policy mechanisms or changes that could address many of the injustices presented here. These mechanisms were merely based on our material, so it is likely that a more concentrated deliberative process would identify many more. Examples of these policies included a national referendum on nuclear power in France that could address many of the procedural injustices associated with secrecy and exclusion. In Germany, special tariffs and shared ownership models could make solar energy more inclusive for lower-income groups. In Norway, certification programs could better account for hazardous material inputs such as lithium, cobalt, and rare earth minerals. In Great Britain, smart meter installations could be dovetailed with fuel poverty charity programs to ensure that heating systems are not removed from homes without an adequate replacement. Each of the four low-carbon transitions can thus be better managed and improved so that they become more equal, participatory, environmentally benign, and socially sensitive.

In this way, elements of improved procedural justice such as greater participation and democracy become crucial factors in making sure that low-carbon transitions do not simply repeat or replace the injustices of the old system. After all, many of the same actors, economic forces, and rationalities driving low-carbon transitions were benefitting formerly from fossil fuel-led growth. Whether a transition guides us to a shining apex of energy justice, or dehumanizes us in the murky substrata of inequality and exclusion, is a matter of our own design.

Funding information This project has received funding from the European Union's Horizon 2020 research and innovation program under grant agreement no 730403 "Innovation pathways, strategies and policies for the LowCarbon Transition in Europe (INNOPATHS)". The content of this deliverable does not reflect the official opinion of the European Union. Responsibility for the information and views expressed herein lies entirely with the author(s). 


\section{Appendix}

Table 8 Nineteen most frequently mentioned injustices

\begin{tabular}{|c|c|c|c|}
\hline Transition & Category & Description & $\begin{array}{l}\text { Frequency } \\
\text { (total } n=16 \text { ) }\end{array}$ \\
\hline Germany & Higher energy prices for all & $\begin{array}{l}\text { Everyone will have indirectly subsidized } \\
\text { solar panels and tariffs for those who } \\
\text { are best placed to afford them }\end{array}$ & 14 \\
\hline Great Britain & $\begin{array}{l}\text { Hurting vulnerable groups } \\
\text { (working families) }\end{array}$ & $\begin{array}{l}\text { May pay more for energy due to inflexible } \\
\text { energy consumption patterns }\end{array}$ & 11 \\
\hline France & Unfair to taxpayers & $\begin{array}{l}\text { Future tax payers bearing burden of } \\
\text { decommissioning and waste } \\
\text { management }\end{array}$ & 11 \\
\hline France & Elitism & $\begin{array}{l}\text { French nuclear policy has been state-led, } \\
\text { centralized and secretive }\end{array}$ & 10 \\
\hline France & Externalities (accidents) & $\begin{array}{l}\text { Economic and environmental impacts of a } \\
\text { serious incident or accident }\end{array}$ & 10 \\
\hline Norway & Externalities (congestion) & $\begin{array}{l}\text { Public transport users disadvantaged by } \\
\text { increased congestion from EVs }\end{array}$ & 10 \\
\hline Germany & Job losses and unemployment & $\begin{array}{l}\text { E.g. oil, coal, nuclear, East-West tensions, } \\
\text { far-right tensions }\end{array}$ & 9 \\
\hline Great Britain & Unfair to taxpayers & $\begin{array}{l}\text { Risk that everyone pays in their electricity } \\
\text { and gas bills }\end{array}$ & 9 \\
\hline Norway & Unfair to taxpayers & $\begin{array}{l}\text { Everyone will have indirectly subsidized } \\
\text { EVs regardless of benefit, reduced tax } \\
\text { income for state }\end{array}$ & 9 \\
\hline France & Externalities (waste) & $\begin{array}{l}\text { Future generations will face statistically } \\
\text { higher risk of pollution due to growing } \\
\text { amount of waste }\end{array}$ & 8 \\
\hline France & Higher energy prices for all & $\begin{array}{l}\text { Future generations will bear greatest } \\
\text { economic costs of managing nuclear } \\
\text { phaseout }\end{array}$ & 8 \\
\hline Great Britain & $\begin{array}{l}\text { Hurting vulnerable groups } \\
\text { (elderly) }\end{array}$ & $\begin{array}{l}\text { May not be able to take advantage of new } \\
\text { opportunities such as time of use tariffs } \\
\text { and smart tech }\end{array}$ & 8 \\
\hline Germany & $\begin{array}{l}\text { Hurting vulnerable groups (fuel } \\
\text { poor) }\end{array}$ & $\begin{array}{l}\text { Lack of recognition of people with fuel } \\
\text { poverty and their needs }\end{array}$ & 8 \\
\hline France & $\begin{array}{l}\text { Hurting vulnerable groups } \\
\quad \text { (future generations) }\end{array}$ & $\begin{array}{l}\text { Future generations will face statistically } \\
\text { higher risk of pollution due to growing } \\
\text { amount of nuclear waste }\end{array}$ & 8 \\
\hline Germany & $\begin{array}{l}\text { Hurting vulnerable groups } \\
\quad \text { (future generations) }\end{array}$ & $\begin{array}{l}\text { Less generous FITs have been brought in } \\
\text { that deny benefits to later-arriving users }\end{array}$ & 8 \\
\hline Germany & $\begin{array}{l}\text { Hurting vulnerable groups } \\
\text { (working families) }\end{array}$ & $\begin{array}{l}\text { Doubly burdened from not benefitting } \\
\text { from solar energy while also having to } \\
\text { foot the bill of the FIT }\end{array}$ & 8 \\
\hline France & Job losses and unemployment & $\begin{array}{l}\text { Future citizens will be locked into nuclear } \\
\text { investments and denied benefits of } \\
\text { clean energy }\end{array}$ & 8 \\
\hline Norway & Job losses and unemployment & $\begin{array}{l}\text { Petrol and diesel car makers losing out, } \\
\text { car mechanics and garages }\end{array}$ & 8 \\
\hline Germany & Elitism & $\begin{array}{l}\text { A source of resentment and a symbol of } \\
\text { inequality, who can afford to take part } \\
\text { in the transition }\end{array}$ & 8 \\
\hline
\end{tabular}

Source: Authors. Note: EVs electric vehicles, FIT feed-in tariff 
Open Access This article is distributed under the terms of the Creative Commons Attribution 4.0 International License (http://creativecommons.org/licenses/by/4.0/), which permits unrestricted use, distribution, and reproduction in any medium, provided you give appropriate credit to the original author(s) and the source, provide a link to the Creative Commons license, and indicate if changes were made.

\section{References}

Alberini A, Bigano A, Ščasný M, Zvěřinová I (2018) Preferences for energy efficiency vs. renewables: what is the willingness to pay to reduce CO2 emissions? Ecol Econ 144:171-185

Andrews N, Nwapi C (2018) Bringing the state back in again? The emerging developmental state in Africa's energy sector. Energy Res Soc Sci 41:48-58

Azevedo M et al (2018) Lithium and cobalt: a tale of two commodities, McKinsey\&Company, June. Available at: https://www.mckinsey.com/industries/metals-and-mining/our-insights/lithium-and-cobalt-a-tale-of-twocommodities. Accessed 30.11.2018

Barry J, Ellis G (2011) Beyond consensus? Agonism, republicanism and a low carbon future. Renewable energy and the public: from NIMBY to participation, pp 29-42

[BEIS] Department for Business, Energy \& Industrial Strategy (2018) Smart Meters Implementation Programme 2018 progress update, May 31, Available at https:/www.gov.uk/government/statistics/statistical-release-anddata-smart-meters-great-britain-quarter-1-2018. Accessed 18.10.2018

Bickerstaff K, Walker G and Bulkeley H (Eds) (2013) Energy Justice in a Changing Climate: Social Equity and Low-carbon Energy. Zed books, London

Bickerstaff K (2017) 31. Geographies of energy justice: concepts, challenges and an emerging agenda. Handbook on the Geographies of Energy, p 438

Brown MA et al (2014) Forty years of energy security trends: a comparative assessment of 22 industrialized countries. Energy Res Soc Sci 4:64-77

Burke $\mathrm{M}$ et al (2018) Large potential reduction in economic damages under UN mitigation targets. Nature 557: 549-553

Clean Energy Wire (2018) What German households pay for power. Factsheet. 05 Jun 2018. Available at: https://www.cleanenergywire.org/factsheets/what-german-households-pay-power. Accessed 27.11.2018

Creutzig F et al (2018) Towards demand-side solutions for mitigating climate change. Nat Clim Chang 8:260271

Demski C, Butler C, Parkhill KA, Spence A, Pidgeon NF (2015) Public values for energy system change. Glob Environ Chang 34:59-69

Eckersley R (2004) The green state: rethinking democracy and sovereignty. MIT Press, Cambridge

Eurostat (2018) Energy consumption in households. Available at: https://ec.europa.eu/eurostat/statisticsexplained/index.php/Energy consumption in households. Accessed 30.11.2018

Eurostat (n.d.) Home ownership rate in selected European countries in 2017. Statista Available at: https://www. statista.com/statistics/246355/home-ownership-rate-in-europe/. Accessed 27.11.2018

Evensen D, Demski C, Becker S, Pidgeon N (2018) The relationship between justice and acceptance of energy transition costs in the UK. Appl Energy 222:451-459

Falkner R (2013) The nation-state, international society, and the global environment. In: The handbook of global climate and environment policy. Wiley, New York, pp 251-267

Florini A, Sovacool BK (2009) Who governs energy? The challenges facing global energy governance. Energy Policy 37(12):5239-5248

Fraunhofer ISE (2018) Recent facts about photovoltaics in Germany, July 20, 2018. Available at: https://www. ise.fraunhofer.de/content/dam/ise/en/documents/publications/studies/recent-facts-about-photovoltaics-ingermany.pdf. Accessed 27.11.2018

Geels FW (2014) Regime resistance against low-carbon energy transitions: introducing politics and power in the multi-level perspective. Theory Cult Soc 31(5):21-40

Geels FW, Berkhout F, van Vuuren DP (2016) Bridging analytical approaches for low-carbon transitions. Nat Clim Chang 6(6):576

Geels FW, Sovacool BK, Schwanen T, Sorrell S (2017) Sociotechnical transitions for deep decarbonization. Science 357(6357):1242-1244

Geels F, Schwanen T, Sorrell S, Jenkins K, Sovacool BK (2018) Reducing energy demand through low-carbon innovation: a sociotechnical transitions perspective and thirteen research debates. Energy Res Soc Sci 40:2335 
German Federal Ministry for Economic Affairs and Energy (2017) Renewable energy sources in figures national and international development, 2016. Berlin

Goedkoop F, Devine-Wright P (2016) Partnership or placation? The role of trust and justice in the shared ownership of renewable energy projects. Energy Res Soc Sci 17:135-146

Graetz G (2014) Uranium mining and first peoples: the nuclear renaissance confronts historical legacies. J Clean Prod 84:339-347

Green F, Denniss R (2018) Cutting with both arms of the scissors: the economic and political case for restrictive supply-side climate policies. Clim Chang 150(1-2):73-87

Grubb M (2014) Planetary economics: energy, climate change and the three domains of sustainable development. Routledge

Healy $\mathrm{N}$ et al (2019) Embodied energy injustices: unveiling and politicizing the transboundary harms of fossil fuel extractivism and fossil fuel supply chains. Energy Res Soc Sci 48:219-234

Heptonstall P, Gross R (2018) What's in a bill? How UK household electricity prices compare to other countries, UKERC Technology and Policy Assessment. October 2018. Available at http://www.ukerc.ac. uk/publications/whats-in-a-bill.html. Accessed 27.11.2018

Hopkins N (2018) Ofgem exploited national security law to silence us, whistleblowers claim, The Guardian, 17 September. Available at: https://www.theguardian.com/law/2018/sep/17/ofgem-made-my-life-hellwhistleblowers-say-they-were-threatened-by-regulator. Accessed 30.11.2018

Horne R, Dalton T (2014) Transition to low-carbon? An analysis of socio-technical change in housing renovation. Urban Stud 51(16):3445-3458

House of Commons Science and Technology Committee (2016) Evidence check: smart metering of electricity and gas

International Energy Agency (2018) Nordic EV outlook 2018: insights from leaders in electric mobility. OECD, Paris

IPCC (2019) Global warming of $1.5^{\circ} \mathrm{C}$, an IPCC special report on the impacts of global warming of $1.5^{\circ} \mathrm{C}$ above pre-industrial levels and related global greenhouse gas emission pathways, in the context of strengthening the global response to the threat of climate change, sustainable development, and efforts to eradicate poverty. Available at http://www.ipcc.ch/report/sr15/

Jenkins K, McCauley D, Heffron R, Stephan H, Rehner R (2016) Energy justice: A conceptual review. Energy Res Soc Sci 11:174-182

Johnstone P, Newell P (2018) Sustainability transitions and the state. Environ Innov Soc Trans 27:72-82

Jones BR, Sovacool BK, Sidortsov RV (2015) Making the ethical and philosophical case for "energy justice". Environ Ethics 37(2):145-168

McCauley D, Ramasar V, Heffron RJ, Sovacool BK, Mebratu D, Mundaca L (2019) "Energy justice in the transition to low carbon energy systems: Exploring key themes in interdisciplinary research," Applied Energy 233 pp. 916-921.)

Morris C (2018) Share of German citizen renewable energy shrinking, 7 February. Available at: https://energytransition.org/2018/02/share-of-german-citizen-renewable-energy-shrinking/. Accessed 03.12 .2018

Mulvaney D (2013) Opening the black box of solar energy technologies: exploring tensions between innovation and environmental justice. Sci Cult 22(3):214 22221

Mulvaney D (2014) Are green jobs just jobs? Cadmium narratives in the life cycle of photovoltaics. Geoforum $54: 178-186$

National Audit Office (NAO) (2018) Rolling out smart meters, November. Available at: https://www.nao.org. uk/report/rolling-out-smart-meters/\#. Accessed 30.11.2018

Newell P, Mulvaney D (2013) The political economy of the 'just transition'. Geogr J 179(2):132-140

Noel L, Zarazua de Rubens G, Sovacool BK (2018) Optimizing innovation, carbon and health in transport: assessing socially optimal electric mobility and vehicle-to-grid (V2G) pathways in Denmark. Energy 153: 628-637

Ockwell DG, Haum R, Mallett A, Watson J (2010) Intellectual property rights and low-carbon technology transfer: conflicting discourses of diffusion and development. Glob Environ Chang 20(4):729-738

Perez-Guerrero M (1982) Role of energy in the life of mankind: lifestyles and distributive justice. Stud Environ Sci 16:551-564

Schlosberg D, Carruthers D (2010) Indigenous struggles, environmental justice, and community capabilities. Glob Environ Politics 10(4):12-35

Shove E (2010) Beyond the ABC: climate change policy and theories of social change. Environ Plan A 42(6): $1273-1285$

Smith A, Stirling A (2010) The politics of social-ecological resilience and sustainable socio-technical transitions. Ecol Soc 15(1) 
Sovacool BK (2014) What are we doing here? Analyzing fifteen years of energy scholarship and proposing a social science research agenda. Energy Res Soc Sci 1:1-29

Sovacool BK et al (2019) Energy injustice and nordic electric mobility: inequality, elitism, and externalities in qualitative expert perceptions of electrification of vehicle-to-grid (V2G) transport (Ecological Economics, in press)

Ürge-Vorsatz D et al (2014) Measuring the co-benefits of climate change mitigation. Annu Rev Environ Resour 39:549-582

Wecker K (2018) Germany's mining communities brace themselves for post-coal era, DW. Available a: https://www.dw.com/en/germanys-mining-communities-brace-themselves-for-post-coal-era/a-44037149. Accessed 30.11.2018

Weinberg AM (1985) Immortal energy systems and intergenerational justice. Energy Policy 51-59

World Nuclear Association. Nuclear Power in France (2018) September. Available at http://www.world-nuclear. org/information-library/country-profiles/countries-a-f/france.aspx. Accessed 18.10.2018

Yenneti K, Day R (2015) Procedural (in) justice in the implementation of solar energy: the case of Charanaka solar park, Gujarat, India. Energy Policy 86:664-673

Publisher's note Springer Nature remains neutral with regard to jurisdictional claims in published maps and institutional affiliations. 